\title{
HIGH PARENT HETEROSIS AND EVALUATION OF TOMATO (Solanum lycopersicum, L.) HYBRIDS INCORPORATING THE MUTANT RIN GENE \\ Abdel-Ati, K. E. A. ${ }^{1}$; Mahasen. A. M. Ibrahim², Y. M. Ahmed'and Yassmeen W. Hussen ${ }^{2}$ \\ 1- Vegetable Crops Department, Fac. Agric., Cairo Univ. \\ 2- Horticulture Research Institute, Agric. Res. Center.
}

\begin{abstract}
This investigation was conducted in the research facilities of the Horticulture Research Institute during the period from 2003 to 2006 to produce and evaluate some tomato hybrids having ripening inhibitor mutant gene rin and study effect of this gene on some quality characters, yield and fruit shelf life. Twenty four tomato cvs. were crossed as female parents with Incridible cv. as male parent. The cultivar Incridible carries rin mutant gene. Parents and $F_{1}$ populations were planted in RCBD with 4 replicates in two successive summer seasons 2005 and 2006 in open field to evaluate them. It was found that the hybrids Black From Tula $\times$ Incridible and VFNT $\times$ Incridible produced the highest significant early yield (7.7 and 6.85 ton /feddan, respectively). Nine hybrids out of them exhibited significant positive high parent heterosis for early yield ranged from 36.81 to $146.79 \%$ with the hybrid Black From Tula $\times$ Incridible having the highest value. The hybrid Strain $B \times$ Incridible produced the highest total yield (17.54 ton/fed.) over all evaluated genotypes; the hybrid Packmore $\mathrm{B} \times$ Incridible exhibited the highest positive high parent heterosis for the same trait. The cultivar Polish produced the highest significant average fruit weight over all evaluated cvs. with mean value $241.4 \mathrm{~g}$. The cultivars Black From Tula, ranked second in this trait having mean value being $205.8 \mathrm{~g}$, the two hybrids VFNT $\times$ Incridible and Castle King $\times$ Incridible showed significant positive high parent heterosis. The cultivar Incridible significantly was the highest value among all evaluated genotypes in fruit firmness, fruit firmness during 35 days, and storage ability. All of the evaluated hybrids were not superior in fruit firmness compared to high parent where they showed significant negative high parent heterosis for these traits.
\end{abstract}

\section{INTRODUCTION}

Tomato, Solanum lycopersicum, L. (previously Lycopersicon esculentum Mill.), is considered one of the most important vegetable crops grown in Egypt. According to the last estimates of the Ministry of Agriculture and Land Reclamation, tomato cultivated area reached 524065 feddan in 2006, yielding $8,576,073$ tons with an average of 16.36 tons/feddan. This vegetable crop is grown through Egypt and in most months of the year.

Tomato hybrid cultivars are preferred in cultivation due to their higher yielding, uniformity, better fruit quality, and their resistance to the most diseases. Tomato fruit ripening involves a number of chemical and physical changes which convert the fruit from a relatively inedible state to one of optimal quality. Several clearly defined changes occur during normal ripening of tomato fruit, including softening, increasing respiration and less well defined changes in flavor and texture are integral parts of the ripening process (Tigchelaar et al., 1978). The ripening inhibitor rin gene, reported as 
a spontaneous recessive mutant, alters several aspects of fruit ripening, shelf life, and fruit softening (Ropinson and Tomes, 1968). Also Buescher and Tigchelaar (1975) reported that fruit of rin mutant remain firm for very long periods.

Buscher et al., (1976) observed that hybrids of normal ripening cultivar $\mathrm{C} 17$ with the nonripening mutants rin and nor ripen normally in terms of color and flavor compared to the normal ripening parent the hybrids have delayed softening, lower pectoly. Fruit of $\mathrm{C} 17 \times$ rin and $\mathrm{C} 17 \times$ nor hybrids were firmer during ripening and after 7 and 14 days in storage than were fruits of the normal parent C17.

The recessive alleles rin and nor were introduced into tomato cv. Ailsa Craig by backcrossing over 5 generations with selection at each stage. A final cross with the wild type produced seeds containing the heterozygous alleles $\mathrm{rin} /{ }^{+}$and nor/+. The firmness of each line was measured using a Durofel spring dynamometer. Fruits containing rin were firmer than those without it (Hobson and Murray 1994).

Lu et al.,(1994) investigated respiration rate, ethylene production, polygalacturonase (PG) activity and fruit firmness in 3 fruit ripening mutants ,viz., alc, nor and rin, the normal cv. 524 Dahong and their $F_{1}$ hybrids. In fruits of the mutants, ethylene and carbon dioxide production were very low and no respiratory or ethylene climacteric was observed. Fruit firmness declined very slowly and only traces of PG could be found in mature fruits. They showed a $300 \%$ increase in storabilitiy compared with cv. 524 Dahong which has a storage life of $60-90$ days. The $F_{1}$ hybrid fruits had a slightly increased storage life compared with normal cv. Sukang 5 and fruit color was qualitatively similar to that of cv. Sukang 5 fruits. Changline, outstanding $F_{1}$ hybrid with long shelf life, high disease resistance and high yield, has been bred with the nor mutant as one of its parents.

Siddiqui et al., (1995) studied physiochemical changes occurring during ripening in parental lines and $\mathrm{F}_{1}$ crosses of mutant rin with 13 other commercial tomato varieties at green mature, yellow and red ripe stages of fruits and found that the fruit weight and ascorbic acid contents increased while fruit wall pressure and acidity decreased during ripening. However, total soluble solids were not affected by ripening in parents as well as in their $F_{1}$ hybrids. The fruits of $F_{1}$ hybrids were smaller in size (relatively larger than mutant rin), less juicy and rich in ascorbic acid content as compared to their normal parents.

Pratta et al., (2000) evaluated genetic interactions affecting fruit quality in wild and cultivated tomato germplasm of the genus Solanum. Plant materials were accessions LA1385 of S. lycopersicum var. cerasiforme ( previously L. esculentum var. cerasiforme) and LA722 of S. pimpinellifolium (previously L. pimpinellifolium), a genotype with normal fruit ripening (cv. Platense) and two mutant genotypes with delayed fruit ripening (nor and rin cultivars) of $S$. lycopersicum, and the hybrids among them. Genetic interaction were measured by the modifications in the number of flowers per cluster and fruit weight, shape, soluble solids content, color and shelf life in the hybrid genotypes relative to parental characters. Wild species and their 
hybrids had more flowers per cluster and lower fruit weight than cultivated accessions. The fruits were also more rounded and had higher soluble solids contents than those of $S$. lycopersicum cultivars. Wild species were found to carry genes that slow fruit ripening and prolong shelf life without impairing color. Such genes from wild species were expressed by the hybrids, thus indicating that they are dominant over the respective alleles of the cultivated tomato. In addition, when wild species were crossed with the nor (non ripening mutant) cultivar, the detrimental effects of the mutant on color were cancelled and fruit shelf life was prolonged.

Sixty $F_{1}$ hybrids involving ripening mutants nor, rin and alc were evaluated for quality traits. Female lines IPA-3, UC-82B, San Pedro and WIR4285 and mutant testers nor Rutger and rin T-3 were the superior combiners to improve majority of the quality traits (Dhatt et al., 2001).

Dhatt et al., (2002) reviewed the implications and potentials of tomato ripening mutants, viz., rin, nor and alc, in prolonging shelf life. These single recessive gene mutations alter respiration, ethylene evolution and ultimately, shelf life of fruits. The effect is more pronounced in homozygotes, where fruits do not develop normal color even with the treatment of ethylene or ethylene analogues. In heterozygotes, gene expression is additive and fruits develop accexperimental plottable color with 100 to $400 \%$ increase in shelf life. The ripening inhibitor genes are not associated with firmness; hence, their transfer into firm fruited varieties can further improve their usefulness for prolonged storage and distant transport.

Kitagawa et al., (2005) developed eight $\mathrm{F}_{1}$ hybrid lines of the rin mutant from various crosses between the lines of the rin mutant and wild type to evaluate the heterozygosity effect of rin on fruit ripening. In the fruit of these $F_{1}$ hybrid lines, the shelf life was improved, but it varied between the lines. One line of the $F_{1}$ hybrids was chosen to investigate the physiological and transcriptional properties of the fruit. Compared with the wild type parent, the $F_{1}$ line showed about half lycopene content and the lower fruit softening.

Abdel-Ati et al., (2000) reported positive heterosis over better-parent for average fruit weight in some hybrids, and it was recorded that all evaluated hybrids exhibited negative high parent heterosis for fruit firmness except one hybrid which showed positive heterosis. (Abdel-Ati et al., 2000).

Hassan et al., (2000a) evaluated $21 \mathrm{~F}_{1}$ hybrids in 1996 and reevaluated 14 of them in 1997. They found that most of the evaluated hybrids exhibited positive heterosis over their respective better parents for early yield. Also, they found that most of the evaluated hybrids exhibited positive betterparent heterosis for total yield. Hassan et al., (2000b) evaluated 21 tomato hybrids in 1996 and 14 hybrids in 1997 for TSS. All evaluated hybrids in 1996 gave negative heterosis values over the better parents in TSS\% content except the hybrids Casstlerock $\times$ VFNT, Clairvil $\times$ Oxheart and Pakmore $B \times$ VFNT which showed low positive heterosis. In 1997, 8 out of 14 hybrids exhibited positive heterosis. Also they reported that 9 out of 21 evaluated hybrids in 1996 and 8 out of 14 evaluated hybrids in 1997 showed positive high parent heterosis for titratable acidity. 
Abdel-Ati, K. E. A. et al.

Bhnan (2002) found that all of the six evaluated hybrids gave positive heterosis over their high parents for early yield, but heterosis was significant only in two hybrids and reported that this evaluated hybrids showed high parent heterosis for total yield, but significance was found in three ones. Negative better parent heterosis was found in all evaluated hybrids for average fruit weight. One out of the six evaluated hybrids exhibited significant negative heterosis over its better parent for fruit flesh thickness and other five hybrids showed non significant positive or negative better parent heterosis. Two out of the 6 evaluated hybrids exhibited non significant positive heterosis for TSS\% over their high parents.

Abo Hamda (2004) evaluated 20 hybrids in 2001 and 2002, 6 out of the 20 evaluated hybrids exhibited positive standard heterosis for early yield 20 at of these 6 hybrids gave significant positive standard heterosis it was found that 6 out of the 20 evaluated hybrids exhibited significant positive standard heterosis for average fruit weight, other three hybrids also exhibited positive heterosis for this trait. Most of the evaluated hybrids showed positive standard heterosis for fruit firmness but significance was found in one hybrids. Negative standard heterosis for fruit flash thickness was found in most of the evaluated hybrids. It was reported that only 8 out of the 20 evaluated hybrids exhibited positive standard heterosis for fruit T.S.S\%.

The objectives of the present investigation were to produce and evaluate some tomato hybrids having the tomato ripening inhibitor mutant gene rin and also to study the effect of this gene on yield and some fruit quality characteristics.

\section{MATERIALS AND METHODS}

This study was conducted during the period from 2003 to 2006 at Kaha Vegetable Research Farm (KVRF), Kalubia Governorate to evaluate some tomato hybrids having the tomato ripening inhibitor mutant gene rin, estimates of heterosis over the high parent $(\mathrm{H} \%)$ and also to study the effect of this gene on yield and some fruit quality characteristics.

Selfing and crossing were carried out in the greenhouse, while evaluations were conducted in the open field at KVRF.

Twenty four tomato cvs,viz., \{Ace 55 VF (USDA-ARS, USA) $\left(P_{1}\right)$, Black From Tula $\left(P_{2}\right)$, Campbelle 1327 VF $\left(P_{3}\right)$, Oregon Spring V $\left(P_{11}\right)$, Polish $\left(P_{14}\right)$, Porter's Pride $\left(P_{15}\right)$, Scotia $\left(P_{17}\right)$, Siletz $\left(P_{18}\right)$, (Tomato Growers Supply Company, USA), Castlehy $105\left(P_{4}\right)$, Castle king $\left(P_{5}\right)$, Strain $B\left(P_{19}\right)$, Super Strain B $\left(P_{21}\right)$, (Sun Seeds, USA), Castlerock $\left(P_{6}\right)$, (Castle Seed Company, USA), Giza $80\left(\mathrm{P}_{7}\right)$, (Institute Horticulture Research ), (Calif. Univ., Davis, USA), Moneymaker $\left(\mathrm{P}_{10}\right)$, Redstar $\left(\mathrm{P}_{16}\right)$, (Tanzi Armando, Parma, Italy), Packmor B $\left(\mathrm{P}_{12}\right)$, (Asgrow, USA), Peto $86\left(\mathrm{P}_{13}\right)$, Super marmande $\left(\mathrm{P}_{20}\right)$, (Petoseed Compny, USA), Line $72\left(\mathrm{P}_{9}\right), \mathrm{UC} 97\left(\mathrm{P}_{22}\right), \mathrm{UC} 204 \mathrm{~A}\left(\mathrm{P}_{23}\right), \mathrm{VFN} 8$ $\left(\mathrm{P}_{24}\right)$ and VFNT $\left(\mathrm{P}_{25}\right)$, (Univ. Calif., Davis USA)\} were crossed as female parent with cv. Incridible $\left(\mathrm{P}_{8}\right)$, (Institute Horticulture Research ), as male parent to produce twenty four $\mathrm{F}_{1}$ hybrids. The cultivar Incridible carries the rin mutant gene. Parental seeds were sown on August 27, 2003 and 
transplanted on September 25, 2003 in the greenhouse. Crosses with cv. Incridible Were conducted from November, 2003 to April, 2004.

The twenty four parents, their $F_{1}$ hybrids and cv. Incridible were evaluated in the open field for two successive summer seasons during 2005 and 2006. In the first season, seeding date was on December 26, 2004 while transplanting was on January 26,2005 . In the second season, seeding date was on December 26, 2005 while transplanting was on January 26, 2006.

In the two seasons, a randomized complete blocks design (RCBD) with 4 replicates was used. The experimental plot (EP) consisted of two rows; each row was $1 \mathrm{~m}$ wide and $4 \mathrm{~m}$. long $\left(E P=8 \mathrm{~m}^{2}\right)$. Plants were set $40 \mathrm{~cm}$. a part and were given the recommended agricultural practices.

\section{Characteristics measured:}

The following characters were measured as follow:

\section{Yield components}

Early yield ton/fed. (EY) was measured as the yield of the first 3 pickings per/plant (10000 plant in feddan). Total yield ton/fed. (TY) was measured as the weight of all fruits harvested at red-ripe stage from each experimental plot.

\section{Fruit quality}

Average fruit weight (AFW) was determined as the mean weight of 10 fruits, randomly chosen, from each experimental plot. Fruit firmness $\mathrm{kg} / \mathrm{cm}^{2}$ (FF) was measured in the red-ripe stage using a needle type pocket penetrometer. Three reading was taken for each fruit by bushing the penetrometer needle slowly at the equatorial plane. Each plot was represented by 10 randomly chosen fruits. Fruit flesh thickness mm (FFT) was determined in a sample of 10 fruits/ plot. Total soluble solids (TSS\%) were determined in at least 10 red-ripe fruits of each plot using a hand refractometer.

\section{Shelf life}

Fruit firmness during 35 days from harvest (FF during 35 days) in a sample of $2 \mathrm{~kg}$ red-ripe fruits of each plot. Were stored in room temperature during storage, damaged fruits were thrown every. Storage ability (SA) was calculated as the number of days which fruits stayed healthy.

Data obtained were statistically analyzed using combined analysis (Gomez and Gomez, 1984) and mean comparisons were based on the Duncan's multiple range test (Steel and Torrie, 1981).

High parent heterosis was estimated the according to the formula (Sinha and Khanna, 1975)

$$
\mathrm{H} \%=\quad F_{1}-H \bar{P}
$$

Where:

$\mathrm{H} \%=$ Heterosis

$\mathrm{F}_{1}=$ First generation mean .

$\overline{\mathrm{HP}}=$ Mean of the high parent. 
Abdel-Ati, K. E. A. et al.

\section{RESULTS AND DISCUSSION}

\section{Early yield (EY)}

The obtained data on EY of tomato genotypes evaluated in the 2005 and 2006 summer seasons are presented in Table 1. Combined analysis of both seasons showed significant differences for this trait among the evaluated genotypes. The hybrids Black From Tula $\times$ Incridible and VFNT $\times$ Incridible produced the highest significant EY (7.7 and 6.85 ton/fed., respectively) without significant differences between them. The hybrids Siletz $\times$ Incridible, Oregon Spring $V \times$ Incridible, Scotia $\times$ Incridible, Strain B $\times$ Incridible and VFN8 $\times$ Incridible ranked second in EY without significant differences between them. Concerning heterosis, most of the evaluated hybrids showed positive high parent heterosis, but 9 out of them exhibited significant positive high parent heterosis for EY ranged from 36.81 to $146.79 \%$ with the hybrid Black From Tula $\times$ Incridible having the highest value. Only one hybrid showed significant negative high parent heterosis for this trait. These results partly agree with those obtained by Bhnan (2002) who found positive high parent heterosis in all evaluated hybrids but 2 out of six evaluated hybrids exhibited significant positive high parent heterosis. On the contrary, AboHamda (2004) reported negative high parent heterosis for EY in most of the evaluated hybrids.

\section{Total yield (TY)}

The obtained data on TY of tomato genotypes evaluated in the 2005 and 2006 summer plantings are presented in Table 1. Combined analysis of both seasons showed significant differences for this character among the evaluated genotypes. The hybrid Strain $\mathrm{B} \times$ Incridible produced the highest TY ( 17.54 ton/fed.) over all evaluated genotypes, but without significant differences from the hybrids Packmore B $\times$ Incridible, VFN $8 \times$ Incridible, VFNT $\times$ Incridible, UC 97-3 $\times$ Incridible, Oregon Spring V $\times$ Incridible, Black From Tula $\times$ Incridible, Giza $80 \times$ Incridible and Castlerock $\times$ Incridible. The lowest TY was produced by cv. UC $204 \mathrm{~A}$. Concerning heterosis, 10 out of the 24 hybrids evaluated showed significant positive high parent heterosis for TY ranged from 45.8 to $111.8 \%$ with the hybrid Packmore $\mathrm{B} \times$ Incridible exhibiting the highest value of heterosis $(111.8 \%)$. Other ten hybrids showed positive heterosis for this trait but without significant differences from their respective high parents. Only three hybrids, viz. Castle King $\times$ Incridible, Campbelle1327VF $\times$ Incridible, and Siletz $\times$ Incridible showed negative heterosis. These results are in agreement with those obtained by Hassan et al., (2000a) and Bhnan (2002) who found that most of $F_{1}$ hybrids evaluated exhibited positive high parent heterosis for TY.

\section{Average fruit weight (AFW)}

Data obtained on AFW of tomato genotypes evaluated in the 2005 and 2006 summer seasons are presented in Table 2. Combined analysis of both seasons showed significant differences among the evaluated genotypes for this trait. The cultivar Polish produced the highest significant AFW over all evaluated cvs and hybrids with AFW being $241.4 \mathrm{~g}$. The cultivars Black From Tula and Redstar ranked second in this trait having AFW values being 205.8 and $173.3 \mathrm{~g}$, respectively with significant differences between them and also 
with other evaluated genotypes. All evaluated hybrids produced fruits having AFW ranged from $57.3 \mathrm{~g}$ to $106.0 \mathrm{~g}$. The lowest value of AFW was obtained from cv. Peto86 $(53.5 \mathrm{~g})$. Only two out of the 24 evaluated hybrids showed significant positive high parent heterosis for AFW reached 44.4 and $31.7 \%$ for the hybrids VFNT $\times$ Incridible and Castle King $\times$ Incridible, respectively. These results are in agreement with Abo-Hamda (2004) who reported significant positive high parent heterosis for this trait in some hybrids and Abdel-Ati et al., (2000) was recorded positive heterosis over the high parent for AFW. On the contrary, significant negative heterosis over their high parents in three out of the six evaluated hybrids (Bhnan 2002).It was evident in most crosses with cv. Incridible that AFW of the hybrids was reduced specially when crossed with large fruited cvs i.e., Ace, Black From Tula, Campbelle1327VF, Line72, Polish, Redstar, and Super marmand.

Fruit firmness $\mathrm{kg} / \mathrm{cm}^{2}$ (FF)

Data obtained on FF of tomato genotypes evaluated in the 2005 and 2006 summer plantings are presented in Table 2. Combined analysis of both seasons showed that the cultivar Incridible significantly had the highest FF among all evaluated genotypes $\left(3.31 \mathrm{~kg} / \mathrm{cm}^{2}\right)$. The lowest FF value was found in the cultivar Polish $\left(1.72 \mathrm{~kg} / \mathrm{cm}^{2}\right)$. The best hybrids in FF were Castlerock $\times$ Incridible, Campbelle $\times$ Incridible, Super Strain B× Incridible, UC 204A $\times$ Incridible, Moneymaker $\times$ Incridible and Peto $86 \times$ Incridible without significant differences between them and all of them were significantly in FF than cv. Incridible. Most of the evaluated hybrids were not significantly different in FF from these 6 hybrids. All evaluated hybrids were not superior in FF compared to high parent Incridible where they showed significant negative high parent heterosis for this character. These results confirmed previous results obtained by Abdel-Ati et al., (2000) who found negative high parent heterosis in most evaluated hybrids for this trait, Bhnan (2002) who reported positive high parent heterosis in 4 out of the 6 evaluated hybrids.

\section{Fruit flesh thickness mm (FFT)}

Data obtained on FFT of tomato genotypes evaluated in the 2005 and 2006 summer plantings are presented in Table 3. Combined analysis of both seasons showed significant differences among the evaluated genotypes. The hybrid Peto $86 \times$ Incridible had the highest value of FFT $(7.2 \mathrm{~mm})$ but without significant differences from as Peto 86, Incridible and UC 973 and the hybrids CastleKing $\times$ Incridible, Super Strain $B \times$ Incridible, Strain $B \times$ Incridible, Castlehy $\times$ Incridible, UC204 $\times$ Incridible, UC $973 \times$ Incridible, VFN $8 \times$ Incridible, and VFNT $\times$ Incridible. The lowest value of FFT was found in fruits of cvs. Oregon Spring and Strain B without significant differences between them. Concerning heterosis, 6 out of 24 evaluated hybrids exhibited non significant positive high parent heterosis with the hybrid Peto $86 \times$ Incridible having the highest value $(5.9 \mathrm{~mm})$. On the contrary, other evaluated hybrids exhibited negative high parent heterosis for this trait but significance was found only in two hybrids, i.e., Black From Tula $\times$ Incridible and Oregon Spring $\times$ Incridible. These results are in agreement with those obtained by Abo-Hamda (2004) who reported non significant positive high parent heterosis for FFT in 5 out of the 20 evaluated hybrids. 
Abdel-Ati, K. E. A. et al.

The same trend was found by Bhnan (2002) who found that five out of the six produced and evaluated hybrids exhibited non significant positive or negative high parent heterosis for this trait.

Total Soluble Solids (TSS\%)

Data obtained on TSS\% of tomato genotypes evaluated in 2005 and 2006 summer plantings are presented in Table 3. Combined analysis of both seasons showed significant differences among the evaluated genotypes. The highest significant TSS\% value was detected in fruits of cvs. Redstar, UC 204 A, Castle King and Line 72, and the hybrid Black From Tula $\times$ Incridible without significant differences between them. The lowest significant TSS\% value was found in fruits of the cv Porter's pride. Concerning heterosis, 3 out of the 24 evaluated hybrids exhibited positive high parent heterosis, but 2 out of these 3 hybrids showed significant high parent hererosis for this trait viz., Black From Tula $\times$ Incridible and Campbelle 1327 VF $\times$ Incridible. These results party agree with those of Hassan et al., (2000b), Bahnan (2002) and Abo-Hamda (2004).

Fruit firmness (FF) during 35 days from harvest $\mathrm{kg} / \mathrm{cm}^{2}$

Data obtained on FF during 35 days from harvest $\mathrm{kg} / \mathrm{cm}^{2}$ of tomato genotypes evaluated in the 2005 and 2006 summer plantings are presented in Table 4. Combined analysis of both seasons exhibited significant differences for this trait among the evaluated genotypes. The cv. Incredible had the highest significant FF during storage period $\left(2.73 \mathrm{~kg} / \mathrm{cm}^{2}\right)$ among all evaluated genotypes. The lowest FF value was found in the cvs. Black From Tula and Scotia $\left(0.00 \mathrm{~kg} / \mathrm{cm}^{2}\right)$. The highest significant hybrids in this trait were Castlerock $\times$ Incridible, Peto $86 \times$ Incridible and Super Strain B $\times$ Incridible without significant differences between them. Concerning heterosis, non of the 24 evaluated hybrids showed significant positive high parent heterosis for FF during storage period. These results are in agreement with those of kitagawa et al., (2005) who found that F1 hybrid line between the line of the rin mutant and wild type showed lower fruit softening. On the contrary, the ripening inhibitor genes are associate with firmness; hence, their transfer into firm-fruited varieties can further improve their usefulness for prolonged storage and distant transport (Dhatt et al., 2002).

\section{Storage ability (SA)}

Data obtained on SA of tomato genotypes evaluated in the 2005 and 2006 summer plantings are presented in Table 4. Combined of both seasons exhibited significant differences for this trait among the evaluated genotypes. The cv. Incredible had the highest significant SA (82.3 days) among all evaluated genotypes. The lowest SA value (7 days) was found in cultivar Black From Tula and Scotia. The best hybrids in SA were Castlerock $\times$ Incridible, Peto $86 \times$ Incridible, Super Strain B $\times$ Incridible, Packmore B $\times$ Incridible and UC 97-3× Incridible having SA ranged from 34.2 to 35 days and without significant differences between them. Concerning heterosis, all evaluated hybrids exhibited significant negative high parent heterosis for fruit storage ability. These results are in agreement with those of Dhatt et al., (2002) who reported that in heterozygote, the fruits with 100 to $400 \%$ increase in shelf life. Also Lu et al., (1994) showed fruits of the heterozygote (alc $\times$ ck1, nor $\times$ ck1, rin $\times$ ck1) were delayed for about 5-7 days compared to that of su kang 5 the normal cultivar. 
Table1. Mean performance of some tomato lines and their $F_{1}$ 'hybrids and high parent heterosis for early and total yield (ton/ fed) in 2005 and 2006 summer seasons ${ }^{z}$.

\begin{tabular}{|c|c|c|c|c|c|c|c|c|c|}
\hline \multirow{2}{*}{\multicolumn{2}{|c|}{ Genotypes }} & \multicolumn{4}{|c|}{ Early yield (ton/ fed. ) } & \multicolumn{4}{|c|}{ Total yield (ton/ fed.) } \\
\hline & & 2005 & 2006 & Mean & $\mathrm{H}^{\mathrm{y} \%}$ & 2005 & 2006 & Mean & $\mathrm{H}^{\mathrm{y} \%}$ \\
\hline Ace 55 VF & (P1) & $2.83 \mathrm{t}-\mathrm{x}$ & $1.58 \mathrm{~s}$ & $2.21 \mathrm{st}$ & & $8.27 \mathrm{i}-\mathrm{n}$ & $6.04 p$ & $7.15 \mathrm{qr}$ & \\
\hline Black From Tula & ( P2) & $2.76 \mathrm{t}-\mathrm{x}$ & $2.02 p-s$ & $2.39 \mathrm{r}-\mathrm{t}$ & & $9.63 \mathrm{~g}-\mathrm{n}$ & $6.95 n-p$ & $8.29 \mathrm{~m}-\mathrm{r}$ & \\
\hline Campbelle 1327 VF & (P3) & $2.59 u-x$ & $3.28 \mathrm{i}-\mathrm{r}$ & $3.43 \mathrm{~m}-\mathrm{q}$ & & $11.55 \mathrm{e}-\mathrm{k}$ & $13.3 \mathrm{~b}-\mathrm{g}$ & $12.42 \mathrm{c}-\mathrm{m}$ & \\
\hline Castlehy & (P4) & ------- & ------- & ------- & & |------- & ------- & \begin{tabular}{|l|l|}
$--\cdot----$ \\
\end{tabular} & \\
\hline CastleKing & (P5) & $5.04 \mathrm{~d}-\mathrm{m}$ & $4.97 \mathrm{~d}-\mathrm{h}$ & $5.01 \mathrm{f}-\mathrm{i}$ & & $10.49 \mathrm{f}-\mathrm{m}$ & $9.95 \mathrm{f}-\mathrm{o}$ & $10.22 \mathrm{f}-\mathrm{r}$ & \\
\hline Castlerock & $(\mathrm{P} 6)$ & $4.71 \mathrm{~g}-\mathrm{q}$ & $4.95 \mathrm{~d}-\mathrm{h}$ & $4.83 \mathrm{~g}-\mathrm{k}$ & & $11.25 \mathrm{e}-\mathrm{I}$ & $14.04 \mathrm{~b}-\mathrm{e}$ & $12.65 \mathrm{c}-\mathrm{I}$ & \\
\hline Giza 80 & ( P7) & $3.65 \mathrm{I}-\mathrm{w}$ & $3.67 \mathrm{~g}-\mathrm{n}$ & $3.661-p$ & & $8.30 \mathrm{i}-\mathrm{n}$ & 7.80 j-p & 8.05 n-r & \\
\hline Incridible & (P8) & $3.61 \mathrm{mw}$ & $2.63 \mathrm{I}-\mathrm{s}$ & $3.12 \mathrm{n}-\mathrm{s}$ & & $8.78 \mathrm{i}-\mathrm{n}$ & $7.04 n-p$ & $7.91 \mathrm{o}-\mathrm{r}$ & \\
\hline Line 72 & (P9) & $3.31 \mathrm{p}-\mathrm{w}$ & $3.54 h-p$ & $3.42 \mathrm{~m}-\mathrm{q}$ & & $6.47 \mathrm{mn}$ & $8.20 \mathrm{i}-\mathrm{p}$ & $7.33 \mathrm{qr}$ & \\
\hline Moneymaker & (P10) & $1.81 X$ & $2.35 \mathrm{~m}-\mathrm{s}$ & $2.08 \mathrm{~T}$ & & $7.93 \mathrm{j}-\mathrm{n}$ & $8.35 \mathrm{i}-\mathrm{p}$ & $8.14 n-r$ & \\
\hline Oregon Spring V & (P11) & 3.26 q-w & $3.14 \mathrm{i}-\mathrm{r}$ & $3.20 \mathrm{~m}-\mathrm{s}$ & & $15.38 \mathrm{a}-\mathrm{e}$ & $11.09 \mathrm{e}-\mathrm{I}$ & $13.23 \mathrm{~b}-\mathrm{i}$ & \\
\hline Packmore B & (P12) & $3.21 \mathrm{r}-\mathrm{w}$ & $3.41 \mathrm{~h}-\mathrm{q}$ & $3.31 \mathrm{~m}-\mathrm{r}$ & & $7.07 \mathrm{I}-\mathrm{n}$ & $8.06 j-p$ & $7.57 \mathrm{p}-\mathrm{r}$ & \\
\hline Peto 86 & (P13) & $5.40 \mathrm{c}-\mathrm{j}$ & $4.94 \mathrm{~d}-\mathrm{h}$ & 5.17 e-h & & $12.14 \mathrm{e}-\mathrm{j}$ & $9.41 \mathrm{~g}-\mathrm{p}$ & $10.77 \mathrm{e}-\mathrm{q}$ & \\
\hline Polish & (P14) & $3.73 \mathrm{I}-\mathrm{v}$ & $3.56 h-p$ & $3.641-p$ & & $8.38 \mathrm{i}-\mathrm{n}$ & $7.19 \mathrm{~m}-\mathrm{p}$ & 7.79 o-r & \\
\hline Porter's pride & (P15) & $3.450-w$ & $3.78 \mathrm{~g}-\mathrm{m}$ & $3.611-p$ & & $9.38 \mathrm{~h}-\mathrm{n}$ & $8.41 \mathrm{i}-\mathrm{p}$ & $8.89 \mathrm{k}-\mathrm{r}$ & \\
\hline Redstar & (P16) & $3.82 \mathrm{I}-\mathrm{v}$ & $3.46 \mathrm{~h}-\mathrm{q}$ & $3.641-p$ & & $9.00 \mathrm{i}-\mathrm{n}$ & $9.88 \mathrm{f}-\mathrm{p}$ & $9.44 \mathrm{~h}-\mathrm{r}$ & \\
\hline Scotia & (P17) & $2.21 \mathrm{Wx}$ & $2.78 \mathrm{k}-\mathrm{s}$ & $2.49 \mathrm{q}-\mathrm{t}$ & & $10.31 \mathrm{f}-\mathrm{m}$ & $8.23 i-p$ & $9.27 \mathrm{i}-\mathrm{r}$ & \\
\hline Sileteze & (P18) & $4.67 \mathrm{~g}-\mathrm{q}$ & $5.12 \mathrm{~d}-\mathrm{g}$ & $4.89 \mathrm{~g}-\mathrm{j}$ & & $9.78 \mathrm{f}-\mathrm{n}$ & $16.50 \mathrm{ab}$ & $13.14 \mathrm{~b}-\mathrm{j}$ & \\
\hline Strain B & (P19) & $3.09 \mathrm{~s}-\mathrm{x}$ & $3.51 \mathrm{~h}-\mathrm{q}$ & $3.30 \mathrm{~m}-\mathrm{r}$ & & $11.50 \mathrm{e}-\mathrm{I}$ & $12.30 \mathrm{c}-\mathrm{h}$ & $11.90 \mathrm{~d}-\mathrm{o}$ & \\
\hline Super marmande & ( P20) & $5.30 \mathrm{c}-\mathrm{k}$ & $4.33 \mathrm{f}-\mathrm{k}$ & $4.81 \mathrm{~g}-\mathrm{k}$ & & $11.26 \mathrm{e}-\mathrm{I}$ & $6.23 \mathrm{op}$ & $8.75 \mathrm{I}-\mathrm{r}$ & \\
\hline Super Strain B & (P21) & 4.78 e-p & $3.78 \mathrm{~g}-\mathrm{m}$ & $4.28 \mathrm{~h}-\mathrm{m}$ & & $12.34 \mathrm{e}-\mathrm{j}$ & $11.31 \mathrm{~d}-\mathrm{k}$ & $11.82 \mathrm{~d}-\mathrm{o}$ & \\
\hline UC 97-3 & (P22) & $6.51 \mathrm{a}-\mathrm{c}$ & $4.63 \mathrm{~d}-\mathrm{i}$ & $5.50 \mathrm{~d}-\mathrm{g}$ & & $13.92 \mathrm{~b}-\mathrm{g}$ & $11.39 \mathrm{~d}-\mathrm{k}$ & $12.65 \mathrm{c}-\mathrm{I}$ & \\
\hline UC $204 \mathrm{~A}$ & (P23) & $2.47 v-x$ & $2.82 \mathrm{k}-\mathrm{s}$ & $2.65 p-t$ & & \begin{tabular}{|c|}
$5.59 \mathrm{n}$ \\
\end{tabular} & $7.231-p$ & $6.41 \mathrm{r}$ & \\
\hline VFN8 & ( P24) & $5.10 \mathrm{c}-\mathrm{I}$ & $2.16 n-s$ & $3.631-p$ & & $12.59 \mathrm{~d}-\mathrm{i}$ & $6.80 n-p$ & $9.69 \mathrm{~h}-\mathrm{r}$ & \\
\hline VFNT & (P25) & $4.83 \mathrm{~d}-\mathrm{o}$ & $2.10 \mathrm{o}-\mathrm{s}$ & $3.46 \mathrm{~m}-\mathrm{q}$ & & $7.51 \mathrm{~K}-\mathrm{n}$ & $6.78 n-p$ & $7.14 \mathrm{qr}$ & \\
\hline$\overline{P_{1} \times P_{8}}$ & & $4.12 \mathrm{i}-\mathrm{t}$ & $3.85 \mathrm{~g}-\mathrm{m}$ & $3.98 \mathrm{i}-0$ & 27.56 & $10.45 \mathrm{f}-\mathrm{m}$ & $12.60 \mathrm{c}-\mathrm{h}$ & $11.53 \mathrm{~d}-\mathrm{p}$ & $45.80^{*}$ \\
\hline$P_{2} \times P_{8}$ & & $7.78 \mathrm{a}$ & $7.62 \mathrm{a}$ & $7.70 \mathrm{a}$ & $146.79^{*}$ & $17.14 \mathrm{ab}$ & $11.67 \mathrm{~d}-\mathrm{j}$ & $14.40 \mathrm{a}-\mathrm{f}$ & $73.70^{*}$ \\
\hline $\mathrm{P}_{3} \times \mathrm{P}_{8}$ & & $4.37 \mathrm{~h}-\mathrm{s}$ & $3.62 \mathrm{~g}-0$ & $3.99 \mathrm{i}-0$ & 16.33 & $11.69 \mathrm{e}-\mathrm{k}$ & $11.46 \mathrm{~d}-\mathrm{k}$ & $11.57 d-p$ & -6.80 \\
\hline $\mathrm{P}_{4} \times \mathrm{P}_{8}$ & & $4.87 \mathrm{~d}-\mathrm{o}$ & $4.2 \mathrm{~g}-\mathrm{I}$ & $4.53 \mathrm{~h}-\mathrm{I}$ & - & $11.19 \mathrm{e}-\mathrm{I}$ & $10.98 \mathrm{e}-\mathrm{m}$ & $11.08 \mathrm{~d}-\mathrm{q}$ & - \\
\hline $\mathrm{P}_{5} \times \mathrm{P}_{8}$ & & $3.92 \mathrm{k}-\mathrm{v}$ & $3.21 \mathrm{i}-\mathrm{r}$ & $3.57 \mathrm{I}-\mathrm{p}$ & $-28.74^{*}$ & $9.59 \mathrm{~g}-\mathrm{n}$ & $8.29 \mathrm{i}-\mathrm{p}$ & $8.94 \mathrm{j}-\mathrm{r}$ & -12.50 \\
\hline $\mathrm{P}_{6} \times \mathrm{P}_{8}$ & & $5.87 b-g$ & $4.54 \mathrm{e}-\mathrm{j}$ & $5.21 \mathrm{e}-\mathrm{h}$ & 7.87 & $12.25 \mathrm{e}-\mathrm{j}$ & $15.04 \mathrm{~b}-\mathrm{d}$ & $13.65 \mathrm{a}-\mathrm{h}$ & 7.90 \\
\hline $\mathrm{P}_{7} \times \mathrm{P}_{8}$ & & $3.98 \mathrm{j}-\mathrm{u}$ & $1.96 \mathrm{q}-\mathrm{s}$ & $2.970-\mathrm{t}$ & -18.85 & $17.15 \mathrm{ab}$ & $11.00 \mathrm{e}-\mathrm{m}$ & $14.07 \mathrm{a}-\mathrm{g}$ & $74.80^{*}$ \\
\hline $\mathrm{P}_{9} \times \mathrm{P}_{8}$ & & $3.83 \mathrm{I}-\mathrm{v}$ & $4.41 \mathrm{f}-\mathrm{j}$ & $4.12 \mathrm{i}-\mathrm{n}$ & 20.47 & $12.21 \mathrm{e}-\mathrm{j}$ & $11.25 \mathrm{~d}-\mathrm{k}$ & $11.73 \mathrm{~d}-\mathrm{o}$ & 48.30 \\
\hline$P_{10} \times P_{8}$ & & $4.72 \mathrm{~g}-\mathrm{q}$ & $2.04 \mathrm{p}-\mathrm{s}$ & $3.38 \mathrm{~m}-\mathrm{r}$ & 8.33 & $13.65 b-h$ & $11.34 \mathrm{~d}-\mathrm{k}$ & $12.50 \mathrm{c}-1$ & $53.60^{*}$ \\
\hline $\mathrm{P}_{11} \times \mathrm{P}_{8}$ & & $6.87 \mathrm{ab}$ & $5.96 \mathrm{c}-\mathrm{e}$ & $6.41 \mathrm{~b}-\mathrm{d}$ & $100.31^{*}$ & $15.66 \mathrm{a}-\mathrm{e}$ & $13.29 \mathrm{~b}-\mathrm{g}$ & $14.47 \mathrm{a}-\mathrm{e}$ & 9.40 \\
\hline$P_{12} \times P_{8}$ & & $3.48 n-w$ & $6.1 \mathrm{~b}-\mathrm{d}$ & $4.79 \mathrm{~g}-\mathrm{k}$ & $44.71^{*}$ & $19.38 \mathrm{a}$ & $14.13 \mathrm{~b}-\mathrm{e}$ & $16.75 \mathrm{ab}$ & $111.80^{*}$ \\
\hline$P_{13} \times P_{8}$ & & $3.54 n-w$ & $3.81 \mathrm{~g}-\mathrm{m}$ & $3.671-p$ & -29.01 & $12.65 \mathrm{~d}-\mathrm{i}$ & $13.15 \mathrm{~b}-\mathrm{g}$ & $12.9 \mathrm{~b}-\mathrm{I}$ & 19.80 \\
\hline $\mathrm{P}_{14} \times \mathrm{P}_{8}$ & & $6.18 b-f$ & $1.84 \mathrm{rs}$ & $4.01 \mathrm{i}-0$ & 10.16 & 15.63 a-e & 9.09 h-p & $12.36 \mathrm{c}-\mathrm{m}$ & $56.30^{*}$ \\
\hline$P_{15} \times P_{8}$ & & $4.56 \mathrm{~g}-\mathrm{r}$ & $3.05 \mathrm{j}-\mathrm{s}$ & $3.80 \mathrm{k}-0$ & 5.26 & 15.20 a-e & $9.20 h-p$ & $12.20 \mathrm{c}-\mathrm{n}$ & 37.20 \\
\hline $\mathrm{P}_{16} \times \mathrm{P}_{8}$ & & $4.94 d-n$ & $2.79 \mathrm{k}-\mathrm{s}$ & $3.86 \mathrm{j}-0$ & 6.04 & $12.14 \mathrm{e}-\mathrm{j}$ & $7.67 \mathrm{k}-\mathrm{p}$ & $9.90 \mathrm{~g}-\mathrm{r}$ & 4.90 \\
\hline$P_{17} \times P_{8}$ & & $5.82 \mathrm{~b}-\mathrm{h}$ & $6.80 \mathrm{a}-\mathrm{c}$ & $6.31 \mathrm{~b}-\mathrm{d}$ & $102.24^{*}$ & $12.73 \mathrm{c}-\mathrm{i}$ & $11.49 \mathrm{~d}-\mathrm{k}$ & $12.11 \mathrm{~d}-\mathrm{n}$ & 30.60 \\
\hline$P_{18} \times P_{8}$ & & $7.63 \mathrm{a}$ & $5.76 \mathrm{c}-\mathrm{f}$ & $6.69 \mathrm{bc}$ & $36.81^{*}$ & $14.13 \mathrm{~b}-\mathrm{f}$ & $12.01 \mathrm{c}-\mathrm{i}$ & $13.07 \mathrm{~b}-\mathrm{k}$ & -0.53 \\
\hline$P_{19} \times P_{8}$ & & $6.22 \mathrm{~b}-\mathrm{e}$ & $5.77 c-f$ & $5.99 b-f$ & $81.52^{*}$ & $15.47 \mathrm{a}-\mathrm{e}$ & $19.60 \mathrm{a}$ & $17.54 \mathrm{a}$ & $47.40^{*}$ \\
\hline $\mathrm{P}_{20} \times \mathrm{P}_{8}$ & & $5.66 \mathrm{~b}-\mathrm{h}$ & $4.67 \mathrm{~d}-\mathrm{i}$ & $5.16 \mathrm{e}-\mathrm{h}$ & 7.28 & $13.94 \mathrm{~b}-\mathrm{g}$ & $11.63 \mathrm{~d}-\mathrm{j}$ & $12.78 \mathrm{~b}-\mathrm{I}$ & 46.10 \\
\hline$P_{21} \times P_{8}$ & & $4.73 \mathrm{f}-\mathrm{q}$ & $3.04 \mathrm{j}-\mathrm{s}$ & $3.88 \mathrm{j}-0$ & -9.35 & $9.98 \mathrm{f}-\mathrm{m}$ & $13.67 b-f$ & $11.83 \mathrm{~d}-\mathrm{o}$ & 0.09 \\
\hline $\mathrm{P}_{22} \times \mathrm{P}_{8}$ & & $5.54 \mathrm{~b}-\mathrm{i}$ & $6.08 \mathrm{~b}-\mathrm{d}$ & $5.81 \mathrm{c}-\mathrm{g}$ & 5.64 & 17.07 a-c & $12.68 \mathrm{c}-\mathrm{h}$ & $14.88 \mathrm{a}-\mathrm{e}$ & 17.60 \\
\hline$P_{23} \times P_{8}$ & & $5.31 \mathrm{c}-\mathrm{k}$ & $5.98 \mathrm{c}-\mathrm{e}$ & $5.65 d-g$ & $81.09^{*}$ & $14.11 \mathrm{~b}-\mathrm{f}$ & 10.56 e-n & $12.34 \mathrm{c}-\mathrm{m}$ & $56.0^{*}$ \\
\hline $\mathrm{P}_{24} \times \mathrm{P}_{8}$ & & $5.52 \mathrm{~b}-\mathrm{i}$ & $6.62 \mathrm{a}-\mathrm{c}$ & $6.07 b-e$ & $67.22^{*}$ & 16.86 a-d & $15.77 \mathrm{bc}$ & $16.31 \mathrm{a}-\mathrm{c}$ & $68.3^{*}$ \\
\hline$P_{25} \times P_{8}$ & & $6.26 b-d$ & $7.44 \mathrm{ab}$ & $6.85 \mathrm{ab}$ & $97.98^{*}$ & $13.68 \mathrm{~b}-\mathrm{h}$ & $16.51 \mathrm{ab}$ & $15.09 a-d$ & $90.8^{*}$ \\
\hline
\end{tabular}

$\mathrm{Y}$ : High parent heterosis values are based on the high parent value for early and total yield (ton/ fed).

$P_{8}$ : Incridible, male Parent.

* : It is found significance between the high parent and $F_{1}$.

z :a,b,c,etc....:Mean comparisons were based on Duncan's multiple range test at 0.05 level 
Abdel-Ati, K. E. A. et al.

Table 2. Mean Mean performance of some tomato lines and their $F_{1}$ 'hybrids and high parent heterosis for average fruit weight $(\mathrm{g})$ and fruit firmness $\left(\mathrm{kg} / \mathrm{cm}^{2}\right)$ in the 2005 and 2006 summer seasons. ${ }^{2}$

\begin{tabular}{|c|c|c|c|c|c|c|c|c|}
\hline \multirow{2}{*}{ Genotypes } & \multicolumn{4}{|c|}{ Average fruit weight ( g ) } & \multicolumn{4}{|c|}{ fruit firmness ( $\mathrm{Kg} / \mathrm{cm} 2$ ) } \\
\hline & 2005 & 2006 & Mean & $\mathrm{H}$ у $\%$ & 2005 & 2006 & Mean & Н у $\%$ \\
\hline Ace 55 VF & $126.6 \mathrm{e}$ & $131.7 \mathrm{de}$ & $129.2 \mathrm{e}$ & & $2.041-q$ & $1.90 \mathrm{qr}$ & 1.97 o-r & \\
\hline Black From Tula ( P2 & $206.5 \mathrm{~b}$ & $205.0 \mathrm{~b}$ & $205.8 \mathrm{~b}$ & & $1.77 \mathrm{qr}$ & $1.85 \mathrm{r}$ & $1.81 \mathrm{c}-\mathrm{i}$ & \\
\hline Jampbelle 1327 VF (P3) & $145.6 \mathrm{~d}$ & $145.1 \mathrm{~d}$ & $145.4 \mathrm{~d}$ & & $1.96 n-q$ & 1.96 o-r & 1.96 o-r & \\
\hline Castlehy $\quad$ (P4) & - & - & - & & - & - & - & \\
\hline CastleKing & $82.2 \mathrm{j}-\mathrm{n}$ & $78.6 \mathrm{I}-\mathrm{r}$ & $80.4 k-q$ & & $1.96 n-q$ & $1.97 \mathrm{o}-\mathrm{r}$ & 1.97 o-r & \\
\hline Castlerock & $84.5 \mathrm{i}-\mathrm{m}$ & $86.1 \mathrm{j}-0$ & $85.3 \mathrm{i}-\mathrm{n}$ & & $2.76 b-f$ & $2.84 a-f$ & $2.80 \mathrm{~b}-\mathrm{e}$ & \\
\hline Giza 80 & $61.8 \mathrm{r}-\mathrm{u}$ & $60.9 \mathrm{r}-\mathrm{u}$ & $61.4 \mathrm{r}-\mathrm{v}$ & & $2.37 \mathrm{~h}-\mathrm{I}$ & $2.23 \mathrm{k}-\mathrm{q}$ & $2.30 \mathrm{i}-\mathrm{o}$ & \\
\hline Incridible & $66.4 n-u$ & $80.4 \mathrm{k}-\mathrm{q}$ & $73.4 \mathrm{I}-\mathrm{u}$ & & $3.54 \mathrm{a}$ & $3.07 \mathrm{a}$ & $3.31 \mathrm{a}$ & \\
\hline Line 72 & $130.6 \mathrm{e}$ & $138.7 \mathrm{~d}$ & $134.7 \mathrm{~d}-\mathrm{e}$ & & $2.14 \mathrm{k}-\mathrm{p}$ & $2.29 \mathrm{i}-\mathrm{p}$ & $2.22 j-p$ & \\
\hline Moneymaker & $59.4 r-u$ & $60.7 \mathrm{r}-\mathrm{u}$ & $60.1 \mathrm{~s}-\mathrm{v}$ & & $2.15 \mathrm{j}-\mathrm{o}$ & $2.28 \mathrm{i}-\mathrm{p}$ & $2.22 j-p$ & \\
\hline Oregon Spring V P11 & $61.7 \mathrm{r}-\mathrm{u}$ & $60.8 \mathrm{r}-\mathrm{u}$ & $61.3 \mathrm{r}-\mathrm{v}$ & & $1.80 \mathrm{p}-\mathrm{r}$ & $1.81 \mathrm{r}$ & $1.81 \mathrm{q}-\mathrm{r}$ & \\
\hline Packmore B $\quad$ P12 & $111.8 \mathrm{f}$ & $111.7 \mathrm{fg}$ & $111.8 \mathrm{f}$ & & $1.880-r$ & $1.92 p-r$ & $1.90 p-r$ & \\
\hline Peto 86 & $54.7 \mathrm{u}$ & $52.2 \mathrm{u}$ & $53.5 \mathrm{v}$ & & $3.04 \mathrm{~b}$ & $2.99 \mathrm{ab}$ & $3.02 \mathrm{~B}$ & \\
\hline Polish & $238.1 \mathrm{a}$ & $244.6 \mathrm{a}$ & $241.4 \mathrm{a}$ & & $1.63 \mathrm{r}$ & $1.80 r$ & $1.72 \mathrm{r}$ & \\
\hline Porter's pride & $80.4 j-p$ & $80.5 \mathrm{k}-\mathrm{q}$ & $80.5 \mathrm{k}-\mathrm{q}$ & & $2.12 k-p$ & $1.980-r$ & $2.05 m-q$ & \\
\hline Redstar & $172.8 \mathrm{c}$ & $173.7 \mathrm{c}$ & $173.3 \mathrm{c}$ & & 2.25 in & $2.07 n-r$ & $2.16 \mathrm{k}-\mathrm{p}$ & \\
\hline Scotia & $69.1 \mathrm{~m}-\mathrm{u}$ & $87.9 \mathrm{j}-\mathrm{n}$ & $78.5 \mathrm{k}-\mathrm{r}$ & & $1.81 \mathrm{p}-\mathrm{r}$ & $2.03 n-r$ & $1.92 p-r$ & \\
\hline Sileteze & $110.6 \mathrm{f}$ & $109 \mathrm{f}-\mathrm{h}$ & $109.8 \mathrm{f}$ & & $2.03 \mathrm{~m}-\mathrm{q}$ & $2.16 \mathrm{~m}-\mathrm{r}$ & $2.10 \mathrm{l}-\mathrm{q}$ & \\
\hline Strain B & $73.9 \mathrm{k}-\mathrm{r}$ & $79.7 \mathrm{k}-\mathrm{q}$ & $76.8 \mathrm{k}-\mathrm{s}$ & & $2.28 \mathrm{~h}-\mathrm{n}$ & $2.58 \mathrm{~d}-\mathrm{k}$ & $2.43 \mathrm{f}-\mathrm{I}$ & \\
\hline Super marmande & $110.1 \mathrm{f}$ & 117.3 ef & $113.7 \mathrm{f}$ & & 1.92 o-r & $2.12 \mathrm{~m}-\mathrm{r}$ & $2.02 n-r$ & \\
\hline Super Strain B & $67.9 \mathrm{n}-\mathrm{u}$ & $70.7 \mathrm{~m}-\mathrm{t}$ & $69.3 n-v$ & & $2.40 \mathrm{~g}-\mathrm{k}$ & $2.53 \mathrm{e}-\mathrm{I}$ & $2.47 \mathrm{e}-\mathrm{k}$ & \\
\hline UC 97-3 & $88.3 \mathrm{~h}-\mathrm{I}$ & $90.9 \mathrm{i}-\mathrm{I}$ & $89.62 \mathrm{~g}-\mathrm{I}$ & & $2.73 \mathrm{~b}-\mathrm{g}$ & $2.46 \mathrm{~g}-\mathrm{m}$ & $2.60 \mathrm{c}-\mathrm{i}$ & \\
\hline UC 204A & $62.6 \mathrm{q}-\mathrm{u}$ & $63.6 \mathrm{q}-\mathrm{u}$ & $63.1 q-v$ & & $2.85 \mathrm{bc}$ & $2.86 \mathrm{a}-\mathrm{e}$ & $2.86 b-d$ & \\
\hline VFN8 & $102.2 \mathrm{f}-\mathrm{h}$ & $107.0 \mathrm{f}-\mathrm{i}$ & $104.6 \mathrm{f}-\mathrm{h}$ & & $2.13 k-p$ & $2.27 \mathrm{j}-\mathrm{p}$ & $2.20 \mathrm{j}-\mathrm{p}$ & \\
\hline VFNT & $69.3 \mathrm{~m}-\mathrm{u}$ & $70.4 \mathrm{n}-\mathrm{u}$ & $69.9 n-v$ & & $2.33 \mathrm{~h}-\mathrm{m}$ & $253 \mathrm{e}-\mathrm{I}$ & $2.43 \mathrm{f}-\mathrm{I}$ & \\
\hline$P_{1} \times P_{8}$ & $93.9 \mathrm{~g}-\mathrm{j}$ & $92.4 \mathrm{~h}-\mathrm{I}$ & $93.2 \mathrm{~g}-\mathrm{k}$ & & $2.40 \mathrm{~g}-\mathrm{k}$ & $2.86 \mathrm{a}-\mathrm{e}$ & $2.63 \mathrm{c}-\mathrm{i}$ & $-20.3^{*}$ \\
\hline $\mathrm{P}_{2} \times \mathrm{P}_{8}$ & $67.3 n-u$ & $64.4 p-u$ & $6.90-\mathrm{v}$ & $-68.0^{*}$ & $2.32 \mathrm{~h}-\mathrm{m}$ & $2.60 \mathrm{c}-\mathrm{k}$ & $2.46 \mathrm{e}-\mathrm{k}$ & -25.5 \\
\hline$P_{3} \times P_{8}$ & $78.7 \mathrm{j}-\mathrm{q}$ & $84.2 \mathrm{j}-0$ & $81.5 \mathrm{j}-0$ & $-43.9^{*}$ & $2.60 \mathrm{c}-\mathrm{h}$ & $2.97 \mathrm{a}-\mathrm{c}$ & $2.79 b-g$ & $-15.8^{\star}$ \\
\hline $\mathrm{P}_{4} \times \mathrm{P}_{8}$ & $64.4 p-u$ & $69.9 \mathrm{n}-\mathrm{u}$ & $67.20-\mathrm{v}$ & - & $2.11 \mathrm{k}-\mathrm{p}$ & $2.21 \mathrm{l}-\mathrm{q}$ & $2.16 \mathrm{k}-\mathrm{p}$ & - \\
\hline$P_{5} \times P_{8}$ & $105.9 \mathrm{fg}$ & $105.8 \mathrm{f}-\mathrm{i}$ & $105.9 \mathrm{fg}$ & $31.7^{*}$ & $2.55 \mathrm{c}-\mathrm{i}$ & $2.61 \mathrm{c}-\mathrm{j}$ & $2.58 \mathrm{c}-\mathrm{i}$ & $-21.8^{*}$ \\
\hline$P_{6} \times P_{8}$ & $62.7 q-u$ & $64.3 p-u$ & $63.5 p-v$ & $-25.6^{*}$ & $2.98 \mathrm{~b}$ & $2.79 \mathrm{a}-\mathrm{g}$ & $2.89 \mathrm{bc}$ & -12.4 \\
\hline $\mathrm{P}_{7} \times \mathrm{P}_{8}$ & $65.0 \mathrm{o}-\mathrm{u}$ & $77.9 \mathrm{l}-\mathrm{s}$ & $71.5 \mathrm{~m}-\mathrm{u}$ & -2.6 & $2.77 \mathrm{~b}-\mathrm{e}$ & $2.48 \mathrm{f}-\mathrm{m}$ & $2.63 c-i$ & -20.3 \\
\hline $\mathrm{P}_{9} \times \mathrm{P}_{8}$ & $57.4 \mathrm{~s}-\mathrm{u}$ & $60.5 \mathrm{r}-\mathrm{u}$ & $59.0 \mathrm{t}-\mathrm{v}$ & $-56.2^{*}$ & $2.35 \mathrm{~h}-\mathrm{m}$ & $2.31 \mathrm{~h}-\mathrm{o}$ & 2.33 h-n & -29.4 \\
\hline$P_{10} \times P_{8}$ & $67.3 n-u$ & $68.60-u$ & $68.0 \mathrm{n}-\mathrm{v}$ & -7.4 & $2.48 \mathrm{~d}-\mathrm{j}$ & $2.88 \mathrm{a}-\mathrm{e}$ & $2.68 \mathrm{~b}-\mathrm{h}$ & $-18.8^{\star}$ \\
\hline $\mathrm{P}_{11} \times \mathrm{P}_{8}$ & $81.5 \mathrm{j}-\mathrm{n}$ & $80.7 \mathrm{k}-\mathrm{q}$ & $81.1 \mathrm{j}-0$ & 10.5 & $2.35 \mathrm{~h}-\mathrm{m}$ & $2.93 \mathrm{a}-\mathrm{d}$ & $2.64 \mathrm{c}-\mathrm{i}$ & $-20.0^{*}$ \\
\hline$P_{12} \times P_{8}$ & $88.1 \mathrm{~h}-\mathrm{I}$ & 89.4 i-m & 88.8 h-m & $-20.6^{*}$ & 2.45 e-k & $2.64 \mathrm{~b}-\mathrm{i}$ & $2.55 c-j$ & $-23.0^{*}$ \\
\hline$P_{13} \times P_{8}$ & $72.9 \mathrm{I}-\mathrm{t}$ & $75.3 \mathrm{I}-\mathrm{t}$ & $74.1 \mathrm{I}-\mathrm{u}$ & 1.0 & $2.85 \mathrm{bc}$ & $2.87 \mathrm{a}-\mathrm{e}$ & $2.86 \mathrm{bc}$ & -13.3 \\
\hline$P_{14} \times P_{8}$ & $97.7 \mathrm{f}-\mathrm{i}$ & $97.8 \mathrm{gk}$ & $97.8 \mathrm{f}-\mathrm{j}$ & $-59.5^{*}$ & $2.34 \mathrm{~h}-\mathrm{m}$ & $2.57 \mathrm{~d}-\mathrm{I}$ & $2.46 \mathrm{e}-\mathrm{k}$ & $-25.5^{\star}$ \\
\hline$P_{15} \times P_{8}$ & $56.2 \mathrm{u}$ & $58.4 \mathrm{tu}$ & 57.3 uv & -28.8 & $2.34 \mathrm{~h}-\mathrm{m}$ & $2.57 \mathrm{~d}-\mathrm{I}$ & $2.46 \mathrm{e}-\mathrm{k}$ & $-25.5^{\star}$ \\
\hline$P_{16} \times P_{8}$ & $80.7 \mathrm{j}-0$ & $83.5 \mathrm{j}-0$ & $82.1 \mathrm{j}-0$ & $-52.6^{*}$ & $2.42 \mathrm{~g}-\mathrm{k}$ & $2.67 \mathrm{~b}-\mathrm{h}$ & $2.55 \mathrm{c}-\mathrm{j}$ & $-22.7^{*}$ \\
\hline$P_{17} \times P_{8}$ & $81.1 \mathrm{j}-0$ & $80.3 \mathrm{k}-\mathrm{q}$ & 80.7 k-p & 2.8 & $2.43 \mathrm{~g}-\mathrm{k}$ & $2.38 \mathrm{~h}-\mathrm{n}$ & $2.41 \mathrm{~h}-\mathrm{I}$ & $-27.0^{*}$ \\
\hline $\mathrm{P}_{18} \times \mathrm{P}_{8}$ & $98.2 \mathrm{f}-\mathrm{i}$ & $99.4 \mathrm{~g}-\mathrm{j}$ & $98.8 \mathrm{f}-\mathrm{i}$ & -10.0 & $2.49 \mathrm{~d}-\mathrm{j}$ & $2.27 \mathrm{j}-\mathrm{p}$ & $2.38 \mathrm{~h}-\mathrm{m}$ & -27.9 \\
\hline$P_{19} \times P_{8}$ & $73.2 \mathrm{I}-\mathrm{s}$ & $79.1 \mathrm{I}-\mathrm{r}$ & $76.2 \mathrm{k}-\mathrm{t}$ & -0.8 & $2.44 \mathrm{f}-\mathrm{k}$ & $2.47 \mathrm{f}-\mathrm{m}$ & $2.46 \mathrm{e}-\mathrm{k}$ & -25.5 \\
\hline$P_{20} \times P_{8}$ & $56.8 \mathrm{tu}$ & $59.6 \mathrm{~s}-\mathrm{u}$ & 58.2 uv & $-48.8^{*}$ & $2.30 \mathrm{~h}-\mathrm{m}$ & $2.48 \mathrm{f}-\mathrm{m}$ & 2.39 h-m & $-27.6^{*}$ \\
\hline$P_{21} \times P_{8}$ & $64.5 p-u$ & $73.9 \mathrm{I}-\mathrm{t}$ & $69.2 n-v$ & -5.7 & $2.73 b-g$ & $2.84 \mathrm{a}-\mathrm{f}$ & $2.79 \mathrm{~b}-\mathrm{f}$ & -15.5 \\
\hline $\mathrm{P}_{22}(\mathrm{P} 8$ & $89.2 \mathrm{~h}-\mathrm{k}$ & $90.4 \mathrm{i}-\mathrm{I}$ & $89.8 \mathrm{~g}-\mathrm{I}$ & 0.2 & $2.39 \mathrm{~h}-\mathrm{k}$ & 2.91 a-d & $2.65 c-i$ & -19.7 \\
\hline P23 ( P8 & $67.4 \mathrm{n}-\mathrm{u}$ & $71.0 \mathrm{~m}-\mathrm{t}$ & $69.2 n-v$ & -5.7 & $2.79 \mathrm{~b}-\mathrm{d}$ & $2.79 \mathrm{a}-\mathrm{g}$ & $2.79 \mathrm{~b}-\mathrm{e}$ & -15.5 \\
\hline P24 ( P8 & $78.8 \mathrm{j}-\mathrm{q}$ & $82.6 \mathrm{j}-\mathrm{p}$ & $80.7 \mathrm{k}-\mathrm{q}$ & $-22.8^{*}$ & $2.31 \mathrm{~h}-\mathrm{m}$ & $2.78 \mathrm{a}-\mathrm{g}$ & $2.55 c-j$ & -22.7 \\
\hline P25 ( P8 & $105.6 \mathrm{fg}$ & $106.3 \mathrm{f}-\mathrm{i}$ & $106.0 \mathrm{fg}$ & $44.4^{*}$ & $2.43 \mathrm{~g}-\mathrm{k}$ & $2.59 \mathrm{~d}-\mathrm{k}$ & $2.51 \mathrm{~d}-\mathrm{k}$ & -23.9 \\
\hline
\end{tabular}

$\mathrm{Y}$ : High parent heterosis values are based on the high parent value for average fruit weight ( $\mathrm{g}$ ) and fruit firmness $\left(\mathrm{kg} / \mathrm{cm}^{2}\right)$.

$P_{8}$ : Incridible, male Parent.

* : It is found significance between the high parent and $F_{1}$.

z :a,b,c,etc....:Mean comparisons were based on Duncan's multiple range test at 0.05 level. 
Table 3. Mean performance of some tomato lines and their $F_{1}$ 'hybrids and high parent heterosis for fruit flesh thickness $(\mathrm{mm})$ and fruit TSS\% in the 2005 and 2006 summer seasons ${ }^{2}$.

\begin{tabular}{|c|c|c|c|c|c|c|c|c|c|}
\hline \multirow{2}{*}{\multicolumn{2}{|c|}{ Genotypes }} & \multicolumn{4}{|c|}{ fruit flesh thickness (mm) } & \multicolumn{4}{|c|}{ TSS $\%$} \\
\hline & & 2005 & 2006 & Mean & H у\% & 2005 & 2006 & Mean & H y\% \\
\hline Ace 55 VF & P1) & $5.2 j-n$ & $5.4 \mathrm{k}-\mathrm{m}$ & $5.3 \mathrm{j}-\mathrm{m}$ & & $5.08 \mathrm{~b}$ & $5.10 \mathrm{bc}$ & $5.09 \mathrm{~b}$ & \\
\hline Black From Tula & P2) & $5.8 \mathrm{f}-\mathrm{k}$ & $5.9 \mathrm{f}-\mathrm{m}$ & 5.9 e-k & & $4.30 \mathrm{i}-\mathrm{k}$ & $4.310-\mathrm{s}$ & $4.31 \mathrm{j}-\mathrm{m}$ & \\
\hline Fampbelle $1327 \mathrm{VF}$ & P3 & $5.5 \mathrm{~h}-1$ & $5.5 \mathrm{j}-\mathrm{m}$ & $5.5 \mathrm{~h}-\mathrm{m}$ & & $4.43 \mathrm{e}-j$ & $4.45 h-p$ & $4.44 \mathrm{f}-\mathrm{I}$ & \\
\hline Castlehy & $(\mathrm{P} 4)$ & - & - & - & & - & - & - & \\
\hline CastleKing & $(\mathrm{P} 5)$ & $5.8 \mathrm{f}-\mathrm{k}$ & $5.8 \mathrm{~g}-\mathrm{m}$ & $5.8 \mathrm{f}-\mathrm{k}$ & & $5.48 \mathrm{a}$ & $5.50 \mathrm{a}$ & $5.49 \mathrm{a}$ & \\
\hline Castlerock & $\mathrm{P} 6$ & $5.1 \mathrm{k}-\mathrm{n}$ & $5.2 \mathrm{~m}$ & $5.1 \mathrm{k}-\mathrm{m}$ & & $5.03 \mathrm{~b}$ & $5.00 \mathrm{c}$ & $5.01 \mathrm{~b}$ & \\
\hline Giza 80 & P7 & $5.9 \mathrm{e}-j$ & $5.9 \mathrm{f}-\mathrm{m}$ & 5.9 e-k & & $4.99 \mathrm{~b}$ & $4.99 \mathrm{~cd}$ & $4.99 \mathrm{~b}$ & \\
\hline Incridible & P8 & $6.7 \mathrm{a}-\mathrm{d}$ & $6.6 \mathrm{~b}-\mathrm{g}$ & $6.7 \mathrm{a}-\mathrm{e}$ & & $4.51 \mathrm{~d}-\mathrm{i}$ & $4.53 \mathrm{f}-\mathrm{n}$ & $4.52 \mathrm{~d}-j$ & \\
\hline Line 72 & P9 & $5.5 \mathrm{~h}-\mathrm{l}$ & $5.4 \mathrm{k}-\mathrm{m}$ & $5.4 \mathrm{i}-\mathrm{m}$ & & $5.48 \mathrm{a}$ & $5.47 \mathrm{a}$ & $5.47 \mathrm{a}$ & \\
\hline Moneymaker & P10 & $5.2 j-n$ & $6.5 \mathrm{~b}-\mathrm{h}$ & $5.8 \mathrm{f}-\mathrm{k}$ & & $4.48 \mathrm{e}-j$ & $4.52 \mathrm{f}-\mathrm{n}$ & $4.50 \mathrm{~d}-\mathrm{k}$ & \\
\hline Oregon Spring V & P11 & 3.70 & $3.8 n$ & 3.80 & & $4.68 \mathrm{c}-\mathrm{f}$ & $4.67 \mathrm{e}-\mathrm{g}$ & $4.67 \mathrm{c}-\mathrm{e}$ & \\
\hline Packmore B & P12 & $6.0 \mathrm{~d}-\mathrm{i}$ & $6.3 c-j$ & $6.1 \mathrm{c}-j$ & & $4.61 \mathrm{c}-\mathrm{g}$ & $4.58 \mathrm{f}-\mathrm{m}$ & $4.60 \mathrm{c}-\mathrm{h}$ & \\
\hline Peto 86 & P13 & $6.6 \mathrm{a}-\mathrm{e}$ & $7.0 \mathrm{ad}$ & $6.8 \mathrm{a}-\mathrm{d}$ & & $4.63 \mathrm{c}-\mathrm{g}$ & $4.66 \mathrm{e}-\mathrm{g}$ & $4.64 \mathrm{c}-\mathrm{f}$ & \\
\hline Polish & P14 & $6.1 \mathrm{~d}-\mathrm{i}$ & $6.3 c-j$ & $6.2 \mathrm{~b}-\mathrm{i}$ & & $5.10 \mathrm{~b}$ & $5.13 \mathrm{bc}$ & $5.11 \mathrm{~b}$ & \\
\hline Porter's pride & P15 & $5.4 \mathrm{i}-\mathrm{m}$ & $4.2 n$ & $4.8 \mathrm{mn}$ & & $3.82 \mathrm{~m}$ & $3.87 \mathrm{v}$ & $3.84 p$ & \\
\hline Redstar & P16 & $6.1 \mathrm{~d}-\mathrm{i}$ & $6.3 c-j$ & $6.2 \mathrm{~b}-\mathrm{i}$ & & $5.56 \mathrm{a}$ & $5.60 \mathrm{a}$ & $5.58 \mathrm{a}$ & \\
\hline Scotia & P17 & $4.7 \mathrm{mn}$ & $5.3 \mathrm{~lm}$ & $5.0 \mathrm{~lm}$ & & $4.58 \mathrm{c}-\mathrm{h}$ & $4.64 \mathrm{e}-j$ & $4.61 \mathrm{c}-\mathrm{g}$ & \\
\hline Sileteze & P18 & $4.7 \mathrm{mn}$ & $3.9 n$ & $4.3 \mathrm{no}$ & & $4.68 \mathrm{c}-\mathrm{e}$ & $4.67 \mathrm{e}-\mathrm{g}$ & $4.68 \mathrm{c}-\mathrm{e}$ & \\
\hline Strain B & P19 & 3.60 & $3.8 \mathrm{n}$ & 3.70 & & $4.00 \mathrm{Im}$ & $4.10 \mathrm{tu}$ & $4.05 \mathrm{no}$ & \\
\hline Super marmande & P20 & $5.6 \mathrm{~g}-1$ & $5.4 \mathrm{k}-\mathrm{m}$ & $5.5 \mathrm{~h}-\mathrm{m}$ & & $4.68 \mathrm{c}-\mathrm{f}$ & 4.72 ef & $4.70 \mathrm{~cd}$ & \\
\hline Super Strain B & P21 & $5.5 \mathrm{~h}-1$ & $5.6 \mathrm{i}-\mathrm{m}$ & $5.5 \mathrm{~h}-\mathrm{m}$ & & $4.24 \mathrm{jk}$ & $4.26 \mathrm{p}-\mathrm{t}$ & $4.251-n$ & \\
\hline UC 97-3 & P22 & $6.6 \mathrm{a}-\mathrm{e}$ & $6.9 \mathrm{a}-\mathrm{e}$ & $6.7 \mathrm{a}-\mathrm{e}$ & & $3.93 \mathrm{~lm}$ & 4.00 uv & 3.96 op & \\
\hline UC 204A & P23 & $5.6 \mathrm{~g}-1$ & $5.6 \mathrm{i}-\mathrm{m}$ & $5.6 \mathrm{~g}-1$ & & $5.60 \mathrm{a}$ & $5.60 \mathrm{a}$ & $5.60 \mathrm{a}$ & \\
\hline VFN8 & P24) & $5.9 \mathrm{e}-\mathrm{j}$ & $6.0 \mathrm{f}-\mathrm{m}$ & $6.0 \mathrm{~d}-\mathrm{j}$ & & $4.10 \mathrm{kl}$ & $4.13 \mathrm{tu}$ & $4.11 \mathrm{~m}-\mathrm{O}$ & \\
\hline VFNT & P25 & $4.5 \mathrm{n}$ & $5.8 \mathrm{~g}-\mathrm{m}$ & $5.1 \mathrm{k}-\mathrm{m}$ & & $4.61 \mathrm{c}-\mathrm{g}$ & $4.62 \mathrm{f}-\mathrm{k}$ & $4.62 \mathrm{c}-\mathrm{g}$ & \\
\hline $\mathrm{P}_{1} \times \mathrm{P}_{8}$ & & $5.9 e-j$ & 6.9 a-e & $6.4 b-g$ & -4.5 & $4.41 \mathrm{~g}-\mathrm{j}$ & $4.421-r$ & $4.41 \mathrm{~g}-1$ & $-13.4^{*}$ \\
\hline $\mathrm{P}_{2} \times \mathrm{P}_{8}$ & & $5.4 \mathrm{i}-\mathrm{m}$ & $5.2 \mathrm{~m}$ & $5.3 \mathrm{j}-\mathrm{m}$ & $-20.9^{*}$ & $5.54 \mathrm{a}$ & $5.53 \mathrm{a}$ & $5.53 \mathrm{a}$ & $22.3^{*}$ \\
\hline $\mathrm{P}_{3} \times \mathrm{P}_{8}$ & & $5.5 \mathrm{~h}-1$ & $6.7 b-f$ & $6.1 \mathrm{c}-j$ & -9.0 & $4.78 \mathrm{c}$ & $4.83 \mathrm{de}$ & $4.80 \mathrm{c}$ & $6.2^{*}$ \\
\hline $\mathrm{P}_{4} \times \mathrm{P}_{8}$ & & $6.9 \mathrm{a}-\mathrm{c}$ & 6.9 a-e & $6.9 \mathrm{a}-\mathrm{c}$ & - & $4.35 \mathrm{~h}-\mathrm{j}$ & $4.37 n-r$ & $4.36 \mathrm{i}-\mathrm{I}$ & - \\
\hline $\mathrm{P}_{5} \times \mathrm{P}_{8}$ & & $6.4 \mathrm{~b}-\mathrm{f}$ & $7.6 \mathrm{a}$ & $7.0 \mathrm{ab}$ & 4.5 & $5.14 \mathrm{~b}$ & $5.13 \mathrm{bc}$ & $5.13 \mathrm{~b}$ & $-6.6^{*}$ \\
\hline $\mathrm{P}_{6} \times \mathrm{P}_{8}$ & & $6.0 \mathrm{~d}-\mathrm{i}$ & $6.6 \mathrm{~b}-\mathrm{g}$ & $6.3 b-h$ & -6.0 & $4.74 \mathrm{~cd}$ & $4.68 \mathrm{e}-\mathrm{g}$ & $4.71 \mathrm{~cd}$ & $-6.0^{*}$ \\
\hline $\mathrm{P}_{7} \times \mathrm{P}_{8}$ & & $6.3 \mathrm{c}-\mathrm{g}$ & $6.2 \mathrm{~d}-\mathrm{k}$ & $6.2 \mathrm{~b}-\mathrm{i}$ & -7.5 & $4.30 \mathrm{i}-\mathrm{k}$ & $4.25 \mathrm{q}-\mathrm{t}$ & $4.27 \mathrm{k}-\mathrm{m}$ & $-14.4^{*}$ \\
\hline$P_{9} \times P_{8}$ & & $6.4 \mathrm{~b}-f$ & $6.5 \mathrm{~b}-\mathrm{h}$ & $6.4 b-g$ & -4.5 & $4.58 \mathrm{c}-\mathrm{h}$ & $4.61 \mathrm{f}-1$ & $4.60 \mathrm{c}-\mathrm{h}$ & $-15.9^{*}$ \\
\hline$P_{10} \times P_{8}$ & & $6.0 \mathrm{~d}-\mathrm{i}$ & $6.5 \mathrm{~b}-\mathrm{h}$ & $6.2 \mathrm{~b}-\mathrm{i}$ & -7.5 & $4.61 \mathrm{c}-\mathrm{g}$ & $4.64 \mathrm{e}^{-\mathrm{i}}$ & $4.62 c-g$ & 2.2 \\
\hline$P_{11} \times P_{8}$ & & $5.01-n$ & $6.4 \mathrm{c}-\mathrm{i}$ & $5.7 \mathrm{f}-\mathrm{I}$ & $-14.9^{*}$ & $4.53 \mathrm{c}-\mathrm{i}$ & $4.53 \mathrm{f}-\mathrm{n}$ & $4.53 \mathrm{~d}-\mathrm{j}$ & -3.0 \\
\hline$P_{12} \times P_{8}$ & & $5.9 e-j$ & $6.3 c-j$ & $6.1 \mathrm{c}-\mathrm{j}$ & -9.0 & $4.39 \mathrm{~g}-\mathrm{j}$ & $4.42 \mathrm{k}-\mathrm{r}$ & $4.41 \mathrm{~g}-1$ & -4.1 \\
\hline$P_{13} \times P_{8}$ & & $7.1 \mathrm{ab}$ & $7.3 \mathrm{ab}$ & $7.2 \mathrm{a}$ & 5.9 & $4.38 \mathrm{~g}-\mathrm{j}$ & $4.37 n-r$ & $4.37 \mathrm{~h}-\mathrm{I}$ & $-5.8^{*}$ \\
\hline$P_{14} \times P_{8}$ & & $6.1 \mathrm{~d}-\mathrm{i}$ & $6.2 \mathrm{~d}-\mathrm{k}$ & $6.1 \mathrm{c}-\mathrm{j}$ & -9.0 & $4.6 c-h$ & $4.65 \mathrm{e}-\mathrm{h}$ & $4.62 \mathrm{c}-\mathrm{g}$ & $-9.6^{*}$ \\
\hline$P_{15} \times P_{8}$ & & $6.2 \mathrm{c}-\mathrm{h}$ & $6.0 \mathrm{f}-\mathrm{m}$ & $6.1 \mathrm{c}-j$ & -9.0 & $4.46 \mathrm{e}-\mathrm{j}$ & $4.44 \mathrm{i}-\mathrm{q}$ & $4.45 \mathrm{e}-\mathrm{I}$ & -1.5 \\
\hline$P_{16} \times P_{8}$ & & $5.7 \mathrm{f}-1$ & $6.2 \mathrm{~d}-\mathrm{k}$ & 5.9 e-k & -11.9 & $5.19 \mathrm{~b}$ & $5.19 \mathrm{~b}$ & $5.19 \mathrm{~b}$ & $-7.0^{*}$ \\
\hline$P_{17} \times P_{8}$ & & $5.1 \mathrm{k}-\mathrm{n}$ & $7.1 \mathrm{a}-\mathrm{c}$ & $6.1 \mathrm{c}-\mathrm{j}$ & -9.0 & $4.12 \mathrm{kl}$ & $4.16 \mathrm{~s}-\mathrm{u}$ & $4.14 \mathrm{~m}-\mathrm{O}$ & $-10.2^{*}$ \\
\hline $\mathrm{P}_{18} \times \mathrm{P}_{8}$ & & $6.2 \mathrm{c}-\mathrm{h}$ & $5.7 \mathrm{~h}-\mathrm{m}$ & $6.0 \mathrm{~d}-\mathrm{j}$ & -10.4 & $4.44 \mathrm{e}-\mathrm{j}$ & $4.44 \mathrm{i}-\mathrm{q}$ & $1.44 \mathrm{f}-\mathrm{I}$ & $-5.1^{*}$ \\
\hline$P_{19} \times P_{8}$ & & 6.6 a-e & $7.3 \mathrm{ab}$ & 6.9 a-c & 3.0 & $4.46 \mathrm{e}-j$ & $4.44 \mathrm{i}-\mathrm{g}$ & $4.45 \mathrm{e}-\mathrm{I}$ & -1.5 \\
\hline$P_{20} \times P_{8}$ & & $6.7 \mathrm{a}-\mathrm{d}$ & $6.1 \mathrm{e}-1$ & $6.4 b-g$ & -4.5 & $4.48 \mathrm{e}-\mathrm{j}$ & $4.51 \mathrm{~g}-0$ & $4.49 \mathrm{~d}-\mathrm{k}$ & -4.5 \\
\hline$P_{21} \times P_{8}$ & & $6.7 \mathrm{a}-\mathrm{d}$ & $6.9 \mathrm{a}-\mathrm{e}$ & $6.8 \mathrm{a}-\mathrm{d}$ & 1.5 & $4.42 \mathrm{f}-\mathrm{j}$ & $4.40 \mathrm{~m}-\mathrm{r}$ & $4.41 \mathrm{~g}-\mathrm{I}$ & -2.4 \\
\hline $\mathrm{P}_{22} \times \mathrm{P}_{8}$ & & $6.6 \mathrm{a}-\mathrm{e}$ & $7.0 \mathrm{a}-\mathrm{d}$ & $6.8 \mathrm{a}-\mathrm{d}$ & 1.5 & $4.53 \mathrm{c}-\mathrm{i}$ & $4.56 f-n$ & $4.54 \mathrm{~d}-\mathrm{i}$ & 0.4 \\
\hline$P_{23} \times P_{8}$ & & $7.3 \mathrm{a}$ & $6.5 b-h$ & $6.9 \mathrm{a}-\mathrm{c}$ & 3.0 & $4.62 \mathrm{c}-\mathrm{g}$ & $4.62 \mathrm{f}-\mathrm{I}$ & $4.62 \mathrm{c}-\mathrm{g}$ & $-17.5^{\star}$ \\
\hline$P_{24} \times P_{8}$ & & $6.0 \mathrm{~d}-\mathrm{i}$ & 6.9 a-e & $6.5 \mathrm{a}-\mathrm{f}$ & -3.0 & \begin{tabular}{|c|}
$4.39 \mathrm{~g}-$ \\
\end{tabular} & $4.24 r-t$ & $4.31 \mathrm{j}-\mathrm{m}$ & -4.6 \\
\hline $\mathrm{P}_{25} \times \mathrm{P}_{8}$ & & $6.2 \mathrm{c}-\mathrm{h}$ & $6.7 b-f$ & $6.5 \mathrm{a}-\mathrm{f}$ & -3.0 & $4.58 c-h$ & $4.48 \mathrm{~g}-0$ & $4.53 \mathrm{~d}-j$ & -1.9 \\
\hline
\end{tabular}

$\mathbf{Y}$ : High parent heterosis values are based on the high parent value for fruit flesh thickness $(\mathrm{mm})$ and fruit TSS\%.

$\mathbf{P}_{8}$ : Incridible, male Parent.

* : It is found significance between the high parent and $F_{1}$.

z :a,b,c,etc....:Mean comparisons were based on Duncan's multiple range test at 0.05 level. 
Abdel-Ati, K. E. A. et al.

Table4. Mean performance of some tomato lines and their $F_{1}$ 'hybrids and high parent heterosis for fruit firmness during 35 days from harvest $\left(\mathrm{kg} / \mathrm{cm}^{2}\right)$ and storage ability (days) in 2005 and 2006 summer seasons ${ }^{z}$.

\begin{tabular}{|c|c|c|c|c|c|c|c|c|c|}
\hline \multirow{2}{*}{\multicolumn{2}{|c|}{ Genotypes }} & \multicolumn{4}{|c|}{ Fruit firmness during 35 days } & \multicolumn{4}{|c|}{ storage ability } \\
\hline & & 2005 & 2006 & Mean & $\mathrm{H} \%$ & 2005 & 2006 & Mean & $\mathrm{H}^{\mathrm{y} \%}$ \\
\hline Ace 55 VF & $(\mathrm{P} 1)$ & 0.34 st & $0.32 \mathrm{vw}$ & $0.33 \mathrm{~s}$ & & $14.0 \mathrm{k}$ & $14.0 \mathrm{i}$ & 14.00 & \\
\hline Black From Tula & $(\mathrm{P} 2)$ & $0.00 \mathrm{u}$ & $0.00 x$ & $0.00 \mathrm{t}$ & & 7.01 & $7.0 \mathrm{j}$ & $7.0 \mathrm{P}$ & \\
\hline ampbelle $1327 \mathrm{VF}$ & P3) & $0.24 \mathrm{t}$ & $0.31 \mathrm{vw}$ & $0.28 \mathrm{~s}$ & & $12.3 \mathrm{k}$ & $14.0 \mathrm{i}$ & 13.20 & \\
\hline Castlehy & (P4) & - & - & - & & - & - & - & \\
\hline CastleKing & (P5) & $1.14 \mathrm{~d}-\mathrm{g}$ & $1.07 \mathrm{~g}-\mathrm{k}$ & $1.11 \mathrm{f}-\mathrm{h}$ & & $28.0 \mathrm{~d}-\mathrm{f}$ & $28.0 \mathrm{~cd}$ & 28.0 e-h & \\
\hline Castlerock & (P6) & 1.21 & $1.16 \mathrm{e}-\mathrm{h}$ & 1.19 & & $29.8 c-e$ & $28.0 \mathrm{~cd}$ & $28.9 \mathrm{~d}-\mathrm{g}$ & \\
\hline Giza 80 & (P7) & $0.83 \mathrm{j}-0$ & $0.75 p-r$ & $0.79 \quad m-p$ & & $22.8 \mathrm{~g}-\mathrm{i}$ & $21.0 \mathrm{f}-\mathrm{h}$ & $21.9 \mathrm{k}-\mathrm{m}$ & \\
\hline Incridible & (P8) & $2.70 \quad \mathrm{a}$ & $2.75 \mathrm{a}$ & $2.73 \mathrm{a}$ & & $80.5 \mathrm{a}$ & $84.0 \mathrm{a}$ & $82.3 \mathrm{a}$ & \\
\hline Line 72 & (P9) & $0.70 \mathrm{Im}-\mathrm{q}$ & $0.69 \mathrm{q}-\mathrm{s}$ & $0.70 \quad 0-q$ & & $21.0 \mathrm{hi}$ & $21.0 \mathrm{f}-\mathrm{h}$ & $21.01-n$ & \\
\hline Moneymaker & P10 & $0.66 \quad 0-q$ & $0.67 q-\mathrm{t}$ & $0.67 \mathrm{pq}$ & & 21.021 & $21.0 \mathrm{f}-\mathrm{h}$ & $21.0 \mathrm{I}-\mathrm{n}$ & \\
\hline Oregon Spring V & $\mathrm{P} 11$ & $0.61 \mathrm{p}-\mathrm{r}$ & $0.52 \mathrm{tu}$ & $0.57 \mathrm{qr}$ & & $21.0 \mathrm{hi}$ & $19.3 \mathrm{gh}$ & $20.2 \mathrm{mn}$ & \\
\hline Packmore B & P12) & $0.33 \mathrm{st}$ & $0.32 \mathrm{vw}$ & $0.33 \mathrm{~s}$ & & $14.0 \mathrm{k}$ & $14.0 \mathrm{i}$ & 14.00 & \\
\hline Peto 86 & $\mathrm{P} 13)$ & $1.06 \mathrm{a}-\mathrm{h}$ & $1.06 \mathrm{~g}-\mathrm{k}$ & $1.06 \mathrm{~g}-\mathrm{i}$ & & $28.0 \mathrm{~d}-\mathrm{f}$ & $28.0 \mathrm{~cd}$ & 28.0 e-h & \\
\hline Polish & P14 & $0.29 \mathrm{st}$ & $0.29 w$ & $0.29 \mathrm{~s}$ & & $14.0 \mathrm{k}$ & $14.0 \mathrm{i}$ & 14.00 & \\
\hline Porter's pride & $\mathrm{P} 15$ & 0.39 & $0.30 \mathrm{w}$ & 0.35 & & $15.8 \mathrm{jk}$ & $14.0 \mathrm{i}$ & 14.90 & \\
\hline Redstar & P16 & $0.71 \mathrm{n}-\mathrm{r}$ & $0.70 \mathrm{q}-\mathrm{s}$ & $0.71 \quad 0-q$ & & $21.0 \mathrm{hi}$ & $21.0 \mathrm{f}-\mathrm{h}$ & $21.01-n$ & \\
\hline Scotia & P17) & $0.00 \mathrm{u}$ & $0.00 x$ & $0.00 \mathrm{t}$ & & 7.01 & $7.0 \mathrm{j}$ & $7.0 p$ & \\
\hline Sileteze & $\mathrm{P} 18$ & $0.57 \mathrm{qr}$ & $0.57 \mathrm{~s}-\mathrm{u}$ & $0.57 \mathrm{gr}$ & & $19.3 \mathrm{ij}$ & $19.3 \mathrm{gh}$ & $19.3 \mathrm{mn}$ & \\
\hline Strain B & P19 & $0.91 \mathrm{~h}-\mathrm{l}$ & $1.0 \mathrm{i}-\mathrm{m}$ & $0.96 \mathrm{j}-1$ & & $24.5 \mathrm{f}-\mathrm{h}$ & $26.3 \mathrm{de}$ & $25.4 \mathrm{~h}-\mathrm{j}$ & \\
\hline Super marmande & P20 & $0.47 \mathrm{rs}$ & $0.47 \mathrm{u}-\mathrm{v}$ & $0.47 \mathrm{r}$ & & $19.3 \mathrm{ij}$ & $17.5 \mathrm{hi}$ & $18.4 \mathrm{n}$ & \\
\hline Super Strain B & P21 & $1.25 \mathrm{~cd}$ & $1.24 \mathrm{~d}-\mathrm{f}$ & $1.25 \mathrm{de}$ & & $28.0 \mathrm{~d}-f$ & $28.0 \mathrm{~cd}$ & 28.0 e-h & \\
\hline UC 97-3 & P22 & 0.95 & $1.1 \mathrm{f}-\mathrm{i}$ & $1.03 \mathrm{~h}-\mathrm{j}$ & & $24.5 \mathrm{f}-\mathrm{h}$ & $28.0 \mathrm{~cd}$ & $26.3 \mathrm{~g}-\mathrm{j}$ & \\
\hline UC 204A & $\mathrm{P} 23$ & 0.94 h-k & $0.91 \mathrm{k}-\mathrm{o}$ & $0.93 \quad \mathrm{i}-\mathrm{m}$ & & $24.5 \mathrm{f}-\mathrm{h}$ & $24.5 \mathrm{~d}-\mathrm{f}$ & $24.5 \mathrm{i}-\mathrm{k}$ & \\
\hline VFN8 & P24) & $0.84 \mathrm{j}-\mathrm{o}$ & $0.93 j-n$ & 0.89 j-n & & $22.8 \mathrm{~g}-\mathrm{i}$ & $24.5 \mathrm{~d}-\mathrm{f}$ & $23.7 \mathrm{j}-1$ & \\
\hline VFNT & P25 ) & $0.680-r$ & $0.67 \mathrm{q}-\mathrm{t}$ & $0.68 \mathrm{pq}$ & & $19.3 \mathrm{ij}$ & $19.3 \mathrm{gh}$ & $19.3 \mathrm{mn}$ & \\
\hline & & & & & & & & & \\
\hline$P_{1} \times P_{8}$ & & 0.90 h-m & $0.97 \mathrm{i}-\mathrm{m}$ & $0.94 \mathrm{i}-\mathrm{I}$ & $-65.57^{*}$ & $24.5 \mathrm{f}-\mathrm{h}$ & $26.3 \mathrm{de}$ & $25.4 \mathrm{~h}-\mathrm{j}$ & $-69.1^{*}$ \\
\hline$P_{2} \times P_{8}$ & & 0.86 i-n & $1.05 \mathrm{~g}-\mathrm{k}$ & 0.96 i-I & $-64.84^{*}$ & $24.5 \mathrm{f}-\mathrm{h}$ & $28.0 \mathrm{~cd}$ & $26.3 \mathrm{~g}-\mathrm{j}$ & $-68^{*}$ \\
\hline$P_{3} \times P_{8}$ & & $0.66 \quad 0-q$ & $0.73 p-s$ & $0.700-q$ & $-74.36^{*}$ & $21.0 \mathrm{hi}$ & $22.8 \mathrm{e}-\mathrm{g}$ & $21.9 \mathrm{k}-\mathrm{m}$ & $-73.4^{*}$ \\
\hline $\mathrm{P}_{4} \times \mathrm{P}_{8}$ & & $0.74 \quad \mathrm{I}-\mathrm{q}$ & $0.78 n-q$ & $0.76 n-p$ & - & $24.5 \mathrm{f}-\mathrm{h}$ & $26.3 \mathrm{de}$ & $25.4 \mathrm{~h}-\mathrm{j}$ & - \\
\hline$P_{5} \times P_{8}$ & & $\begin{array}{ll}1.17 & d-f \\
\end{array}$ & $1.26 \mathrm{de}$ & $1.22 \mathrm{~d}-\mathrm{f}$ & $-55.31^{*}$ & $29.8 c-e$ & $31.5 \mathrm{bc}$ & $30.7 \mathrm{de}$ & -62.7 \\
\hline$P_{6} \times P_{8}$ & & $1.75 \quad b$ & $1.74 b$ & $1.75 \mathrm{~b}$ & $-35.9^{*}$ & $35.0 \mathrm{~b}$ & $35.0 \mathrm{~b}$ & $35.0 \mathrm{~b}$ & $-57.5^{\star}$ \\
\hline $\mathrm{P}_{7} \times \mathrm{P}_{8}$ & & $1.25 \mathrm{~cd}$ & $1.25 \mathrm{~d}-\mathrm{f}$ & $1.25 \mathrm{de}$ & $-54.21^{*}$ & $31.5 b-d$ & $31.5 b c$ & $31.5 \mathrm{~cd}$ & $-61.7^{*}$ \\
\hline $\mathrm{P}_{9} \times \mathrm{P}_{8}$ & & $0.94 \quad h-k$ & $0.95 \mathrm{i}-\mathrm{m}$ & $0.95 \mathrm{i}-\mathrm{I}$ & $-65.2^{*}$ & $26.3 \mathrm{e}-\mathrm{g}$ & $26.3 \mathrm{de}$ & $26.3 \mathrm{~g}-\mathrm{j}$ & $-68.0^{*}$ \\
\hline$P_{10} \times P_{8}$ & & $1.01 \mathrm{f}-\mathrm{j}$ & $1.04 \mathrm{~g}-1$ & $1.03 \mathrm{~h}-\mathrm{j}$ & -62.27 & $28.0 \mathrm{~d}-\mathrm{f}$ & $31.5 \mathrm{bc}$ & $29.8 d-f$ & $-63.8^{*}$ \\
\hline$P_{11} \times P_{8}$ & & \begin{tabular}{ll|}
0.61 & $\mathrm{p}-\mathrm{r}$ \\
\end{tabular} & $0.61 \mathrm{r}-\mathrm{u}$ & $0.61 \mathrm{q}$ & $-77.66^{*}$ & \begin{tabular}{|l|}
$21.0 \mathrm{hi}$ \\
\end{tabular} & $21.0 \mathrm{f}-\mathrm{h}$ & $21.0 \mathrm{I}-\mathrm{n}$ & $-74.5^{*}$ \\
\hline$P_{12} \times P_{8}$ & & $\begin{array}{ll}1.43 & c \\
\end{array}$ & $1.47 \mathrm{c}$ & $1.45 \mathrm{c}$ & $-46.89^{*}$ & $33.3 \mathrm{bc}$ & $35.0 \mathrm{~b}$ & 34.2 bc & $-58.4^{*}$ \\
\hline$P_{13} \times P_{8}$ & & 1.79 & $1.79 b$ & $1.79 \mathrm{~b}$ & $-34.43^{*}$ & $35.0 \mathrm{~b}$ & $35.0 \mathrm{~b}$ & $35.0 \mathrm{~b}$ & $-57.5^{\star}$ \\
\hline $\mathrm{P}_{14} \times \mathrm{P}_{8}$ & & $1.29 \mathrm{~cd}$ & $1.3 \mathrm{de}$ & $1.30 \mathrm{de}$ & $-52.38^{*}$ & $31.5 b-d$ & $31.5 \mathrm{bc}$ & $31.5 \mathrm{~cd}$ & $-61.7^{*}$ \\
\hline$P_{15} \times P_{8}$ & & $0.82 \mathrm{j}-\mathrm{o}$ & $0.760-r$ & $0.79 \mathrm{~m}-\mathrm{p}$ & $-71.06^{*}$ & $24.5 \mathrm{f}-\mathrm{h}$ & $22.8 \mathrm{e}-\mathrm{g}$ & $23.7 \mathrm{j}-1$ & $-71.2^{*}$ \\
\hline$P_{16} \times P_{8}$ & & 1.30 & $1.28 \mathrm{de}$ & $1.29 \mathrm{de}$ & -52.75 & $31.5 b-d$ & $31.5 \mathrm{bc}$ & $31.5 \mathrm{~cd}$ & $-61.7^{*}$ \\
\hline$P_{17} \times P_{8}$ & & $0.79 \quad k-p$ & $0.881-p$ & 0.82 I-o & $-69.23^{*}$ & $22.8 \mathrm{~g}-\mathrm{i}$ & $24.5 \mathrm{~d}-\mathrm{f}$ & $23.7 \mathrm{j}-\mathrm{I}$ & $-71.2^{*}$ \\
\hline $\mathrm{P}_{18} \times \mathrm{P}_{8}$ & & 0.82 & $0.93 \mathrm{j}-\mathrm{n}$ & $0.88 \mathrm{k}-\mathrm{n}$ & $-67.77^{*}$ & $22.8 \mathrm{~g}-\mathrm{i}$ & $24.5 \mathrm{~d}-\mathrm{f}$ & $23.7 \mathrm{j}-\mathrm{I}$ & $-71.2^{*}$ \\
\hline$P_{19} \times P_{8}$ & & 1.06 & $1.05 \mathrm{~g}-\mathrm{k}$ & $1.06 \mathrm{~g}-\mathrm{i}$ & $-61.17^{*}$ & $28.0 \mathrm{~d}-\mathrm{f}$ & $28.0 \mathrm{~cd}$ & $28.0 \mathrm{e}-\mathrm{h}$ & $-66.0^{*}$ \\
\hline $\mathrm{P}_{20} \times \mathrm{P}_{8}$ & & $1.05 \mathrm{e}-\mathrm{i}$ & $1.08 \mathrm{~g}-\mathrm{j}$ & $1.07 \mathrm{~g}-\mathrm{i}$ & -60.81 & $28.0 \mathrm{~d}-\mathrm{f}$ & $28.0 \mathrm{~cd}$ & 28.0 e-h & $-66.0^{*}$ \\
\hline$P_{21} \times P_{8}$ & & $1.79 \quad b$ & $1.77 \mathrm{~b}$ & $1.78 \mathrm{~b}$ & $-34.8^{*}$ & $35.0 \mathrm{~b}$ & $35.0 \mathrm{~b}$ & $35.0 \mathrm{~b}$ & $-57.5^{\star}$ \\
\hline $\mathrm{P}_{22} \times \mathrm{P}_{8}$ & & $1.28 \mathrm{~cd}$ & $1.4 \mathrm{~cd}$ & $1.34 \mathrm{~cd}$ & $-50.92^{*}$ & $33.3 \mathrm{bc}$ & $35.0 \mathrm{~b}$ & 34.2 bc & $-58.4^{*}$ \\
\hline$P_{23} \times P_{8}$ & & $0.97 \mathrm{~g}-\mathrm{k}$ & 1.02h-m & $1.00 \mathrm{~h}-\mathrm{k}$ & $-63.37^{*}$ & $26.3 \mathrm{e}-\mathrm{g}$ & $28.0 \mathrm{~cd}$ & $27.2 \mathrm{f}-\mathrm{i}$ & $-67.0^{*}$ \\
\hline$P_{24} \times P_{8}$ & & 0.94 & $0.87 m-p$ & $0.91 \mathrm{j}-\mathrm{m}$ & $-66.67^{*}$ & $26.3 e-g$ & $24.5 \mathrm{~d}-\mathrm{f}$ & $25.4 \mathrm{~h}-\mathrm{j}$ & $-69.1^{*}$ \\
\hline$P_{25} \times P_{8}$ & & 1.13 & $1.2 \mathrm{e}-\mathrm{g}$ & $1.17 \mathrm{e}-\mathrm{g}$ & $-57.14^{*}$ & $29.8 \mathrm{c}-\mathrm{e}$ & $31.5 \mathrm{Bc}$ & $30.7 \mathrm{de}$ & $-62.7^{*}$ \\
\hline
\end{tabular}

$\mathrm{Y}$ : High parent heterosis values are based on the high parent value fruit firmness during 35 days from harvest and storage ability (days) .

$P_{8}$ : Incridible, male Parent.

* : It is found significance between the high parent and $F_{1}$.

z :a,b,c,etc....:Mean comparisons were based on Duncan's multiple range test at 0.05 level. 


\section{REFERENCES}

Abdel-Ati, K. E. A., S. E. S. Moustafa, A. A. Hassan, and A. A. Mohammed. (2000). Development and release of some new tomato hybrids.II. Fruit physical characteristics and their heterosis. Egypt. J. Hort. 27(2):219232.

Abo-Hamda, E. M. H. (2004). Genetics studies on tomato male sterility. M.Sc. Thesis, Fac. Agric., Cairo. Univ.

Bhnan, E. Y. (2002). Genetic studies on tomato. Ph.D. Thesis, Fac. Agric., Cairo Univ. $117 \mathrm{p}$.

Buescher, R. W. and E. C. Tigchelaar .(1975). Pectin esterase, polygalacturonas, cx-celluslase acclivities and softening of the rin tomato mutant . Hort. Science 10 (6) : 624-625.

Buescher, R. W., W. A. Sistrunk, E. C. Tigchelaar and J. Ng. Timothy. (1976). Softening, pectolytic activity, and Storage-life of rin and nor tomato hybrids. Hort. Science 11 (6) : 603-604.

Dhatt, A.S., S. Singh, M.S. Dhaliwal and D.S. Cheema. (2001). Gentic analysis of tomato hybrids incorporating nor, rin and alc allales for quality. Crop improvement 28 (1) : 32-39. (c.a. CAB. Abstr. CD 2002).

Dhatt, A.S., S. Singh, M.S. Dhaliwal and D.S. Cheema. (2002). Tomato ripening mutants rin, nor and alc : a potential germplasm to improve shelf life. Vegetable Science 29 (1) : 1-12. (c.a. CAB. Abstr. CD 2003).

Gomez, A. K. and A. A. Gomez. (1984). Statistical Procedures for Agricultural Research. $2^{\text {nd }}$ ed. John Wiley \& Sons Pub., pp. 139-153.

Hassan, A. A., S. E. S. Moustafa, K. E. A. Abdel-Ati, and A. A. Mohammed. (2000a). Development and release of some new tomato hybrids. I. Parental evaluation, hybrid yield performance and yield heterosis. Egypt. J. Hort. 27(2):201-218.

Hassan, A. A., S. E. S. Moustafa, K. E. A. Abdel-Ati, and A. A. Mohammed. (2000b). Development and release of some new tomato hybrids.III. Hybrid fruit chemical characteristics and their heterosis. Egypt. J. Hort. 27(2):233-248.

Hobson, G. E. and A. J. Murray. (1994). From producer to pantry-using biotechnology to preserve crop quality. Aspects of Applied Biology 39: 95-102. (c.a. CAB. Abstr. CD 1995).

Kitagawa, M., H. Ito, T. Shiina, N. Nakamura, T. Inakuma, T.Kasumi, Y.Ishiguro, K.Yabe and Y. Ito.(2005). Characterization of tomato fruit ripening and analysis of gene expression in $F_{1}$ hyprids of the ripening inhibitor rin mutant. Physiologia Plantarum 123 (3) : 331-338. (c.a. CAB. Abstr. CD 2005/03-2005/05).

Lu, C.G., H.L. Xu, R.C. Yang and W.G. Yu. (1994). Storage-linked physiological characters of tomato carrying fruit ripening mutant genes and their implications in breeding. Jiangsu Journal of Agricultural Sciences 10 (3): 5-10. (c.a. CAB. Abstr. CD 1995).

.Pratta, G., R.Zorzoli and L.A. Picardi. (2000). Genetic interactions affecting tomato fruit quality in wild and cultivated germplasm of lycopersicon spp. Plant Genetic Resources Newsletter 124: 7-12. (c.a. CAB. Abstr. CD 2001). 
Ropinson, R.W. and M.L. Tomes. (1968). Ripening inhibitor: agene with multiple effects on ripening. Rpt. Tom. Genet. Coop. 18: 36-37.

Siddiqui, S., M.K. Banerjee and G. Kalloo. (1995). Physico-chemical changes during ripening of $F_{1}$ crosses of mutant rin and cultivated varieties of tomato. Haryana Journal of Horticultural Science 24 (1): 64-70.(c.a. CAB. Abstr. CD 1997).

Sinha, S. K. and R. Khanna. (1975). Physiological, biochemical and genetic basis of heterosis. Adv. Agron. 27:123-147.

Steel, R. C. D. and J. H. Torrie (1981). Principles and Procedures of Statistics. McGrow-Hill, New York.

Tigchelaar, E.C.,W. B. Mcglasson and R.W. Buescher. (1978). Genetics regulation of tomato fruit ripening. Hort. Science 13 (5) : 508-513.

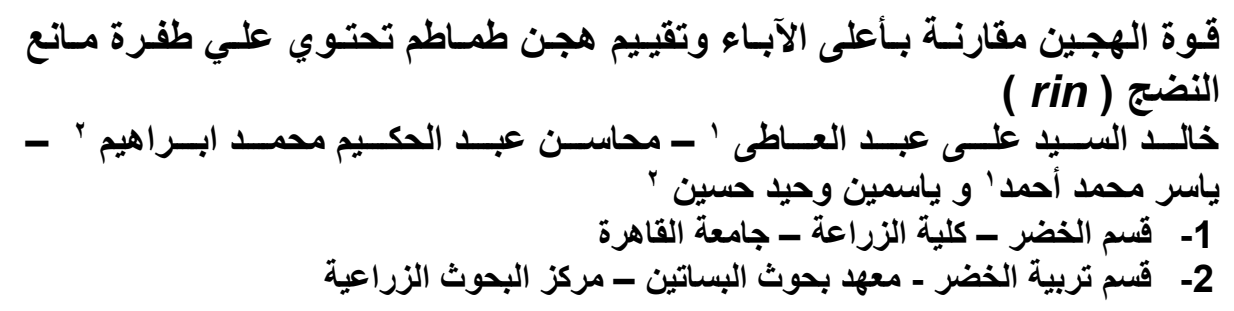

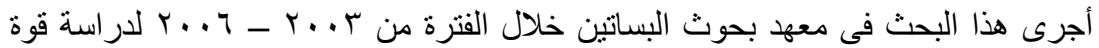

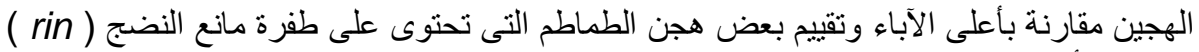

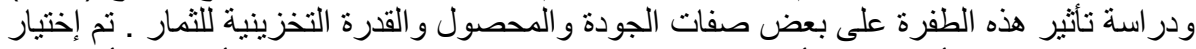

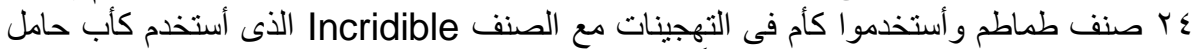

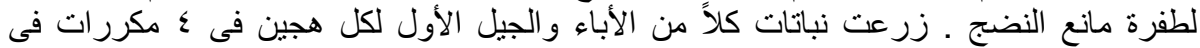

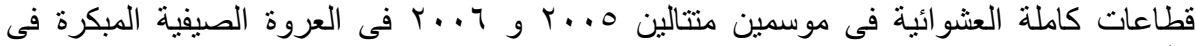
وأظهرت النتائج أن الهجين Strain B × Incridible أعطى أعلى محصول كلى

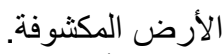

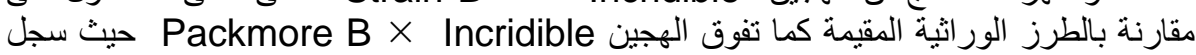

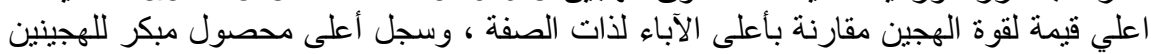
VFNT × Incridible , Black From Tula × Incridible

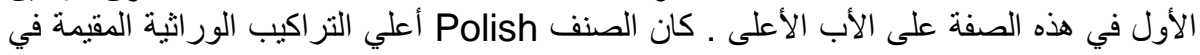

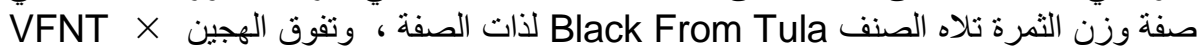

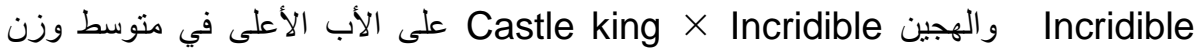

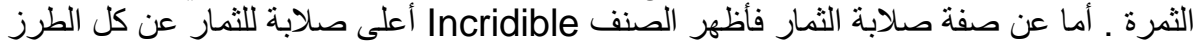

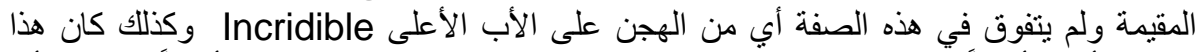

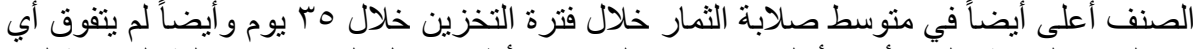

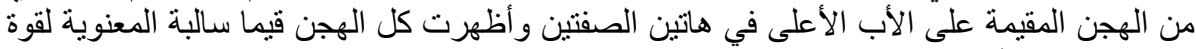

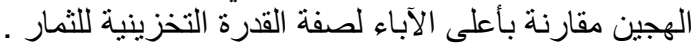

